SUPPORTING INFORMATION

SUPPORTING INFORMATION

\title{
A Non Diels-Alder Approach to the cis-Decalin Core of Branimycin
}

Valentin S. Enev, Martina Drescher and Johann Mulzer,

Institut für Organische Chemie, Währinger Strasse 38, A - 1090 Vienna, Austria 

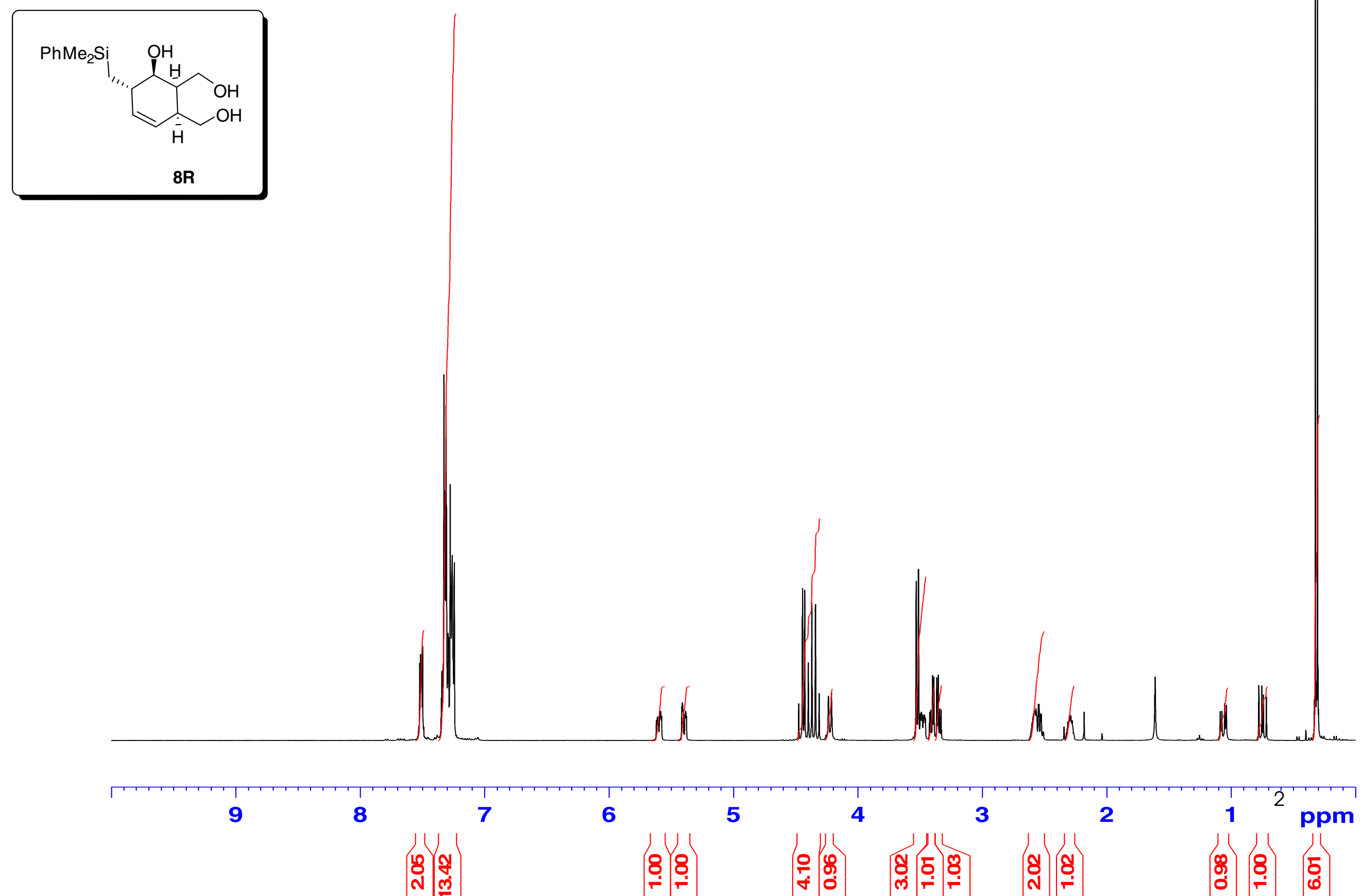

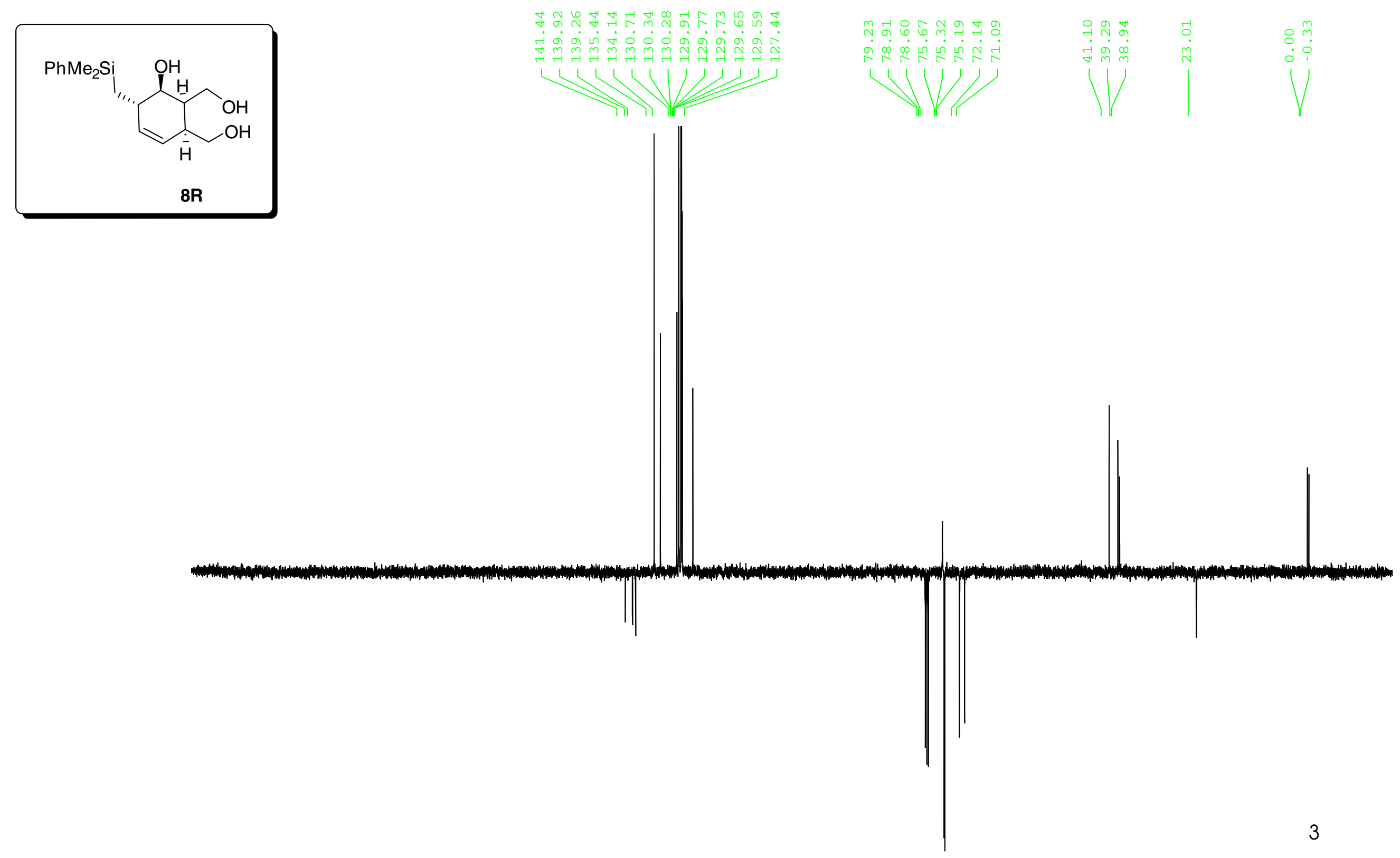

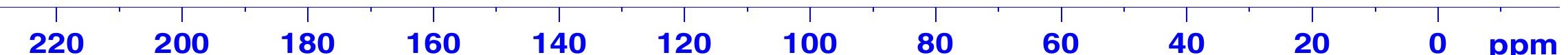




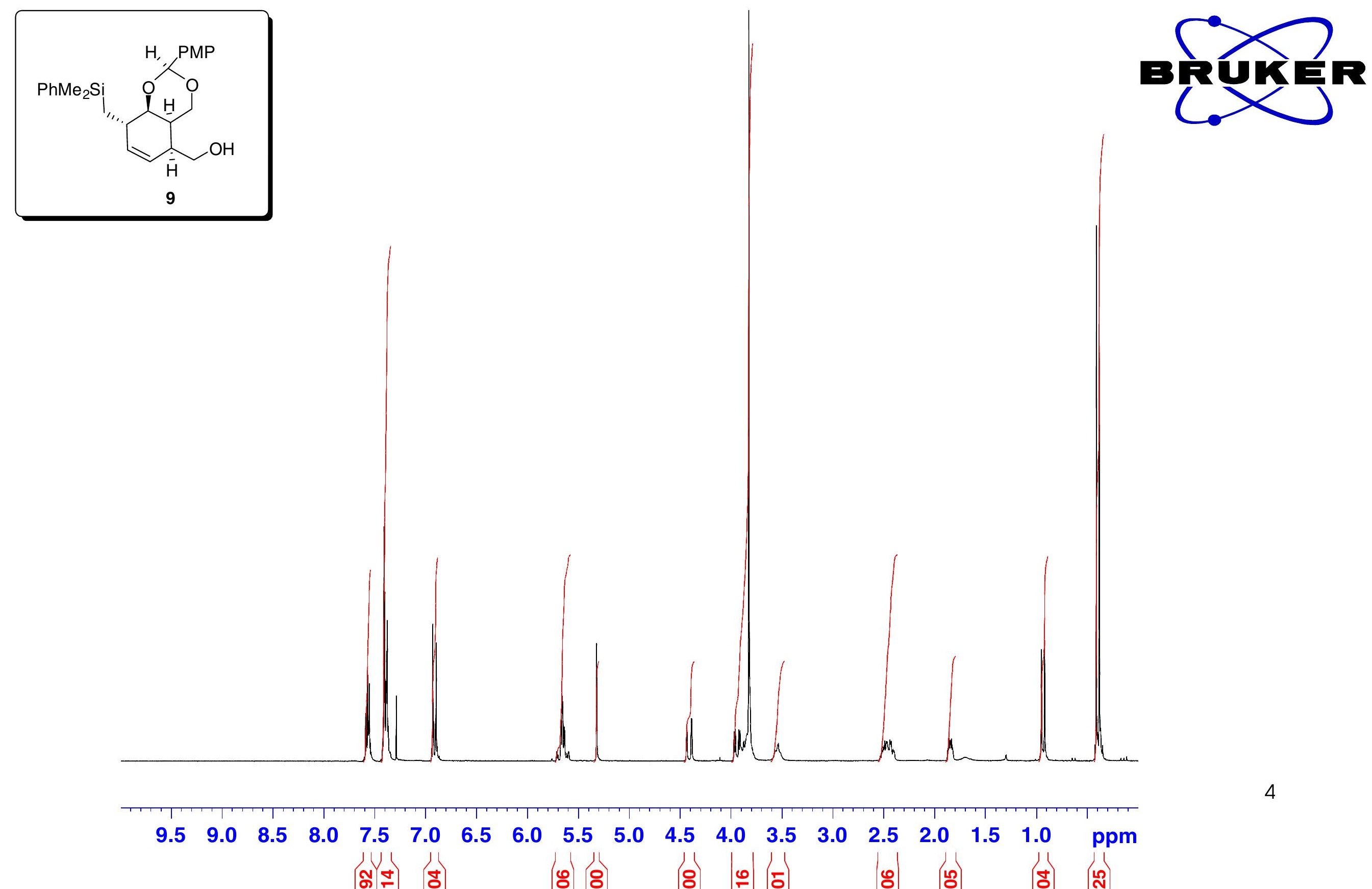



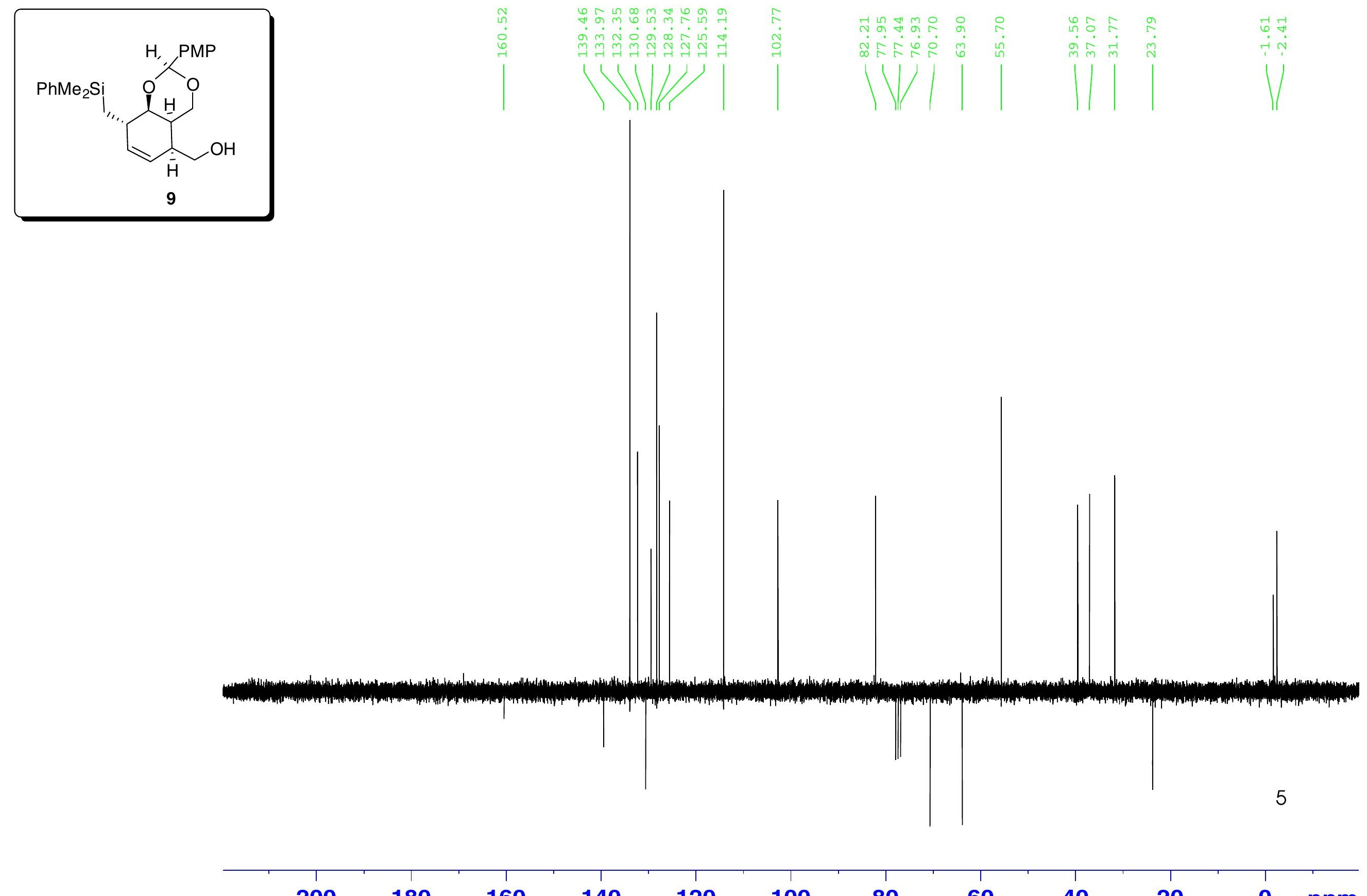

$10 n$

on

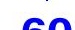



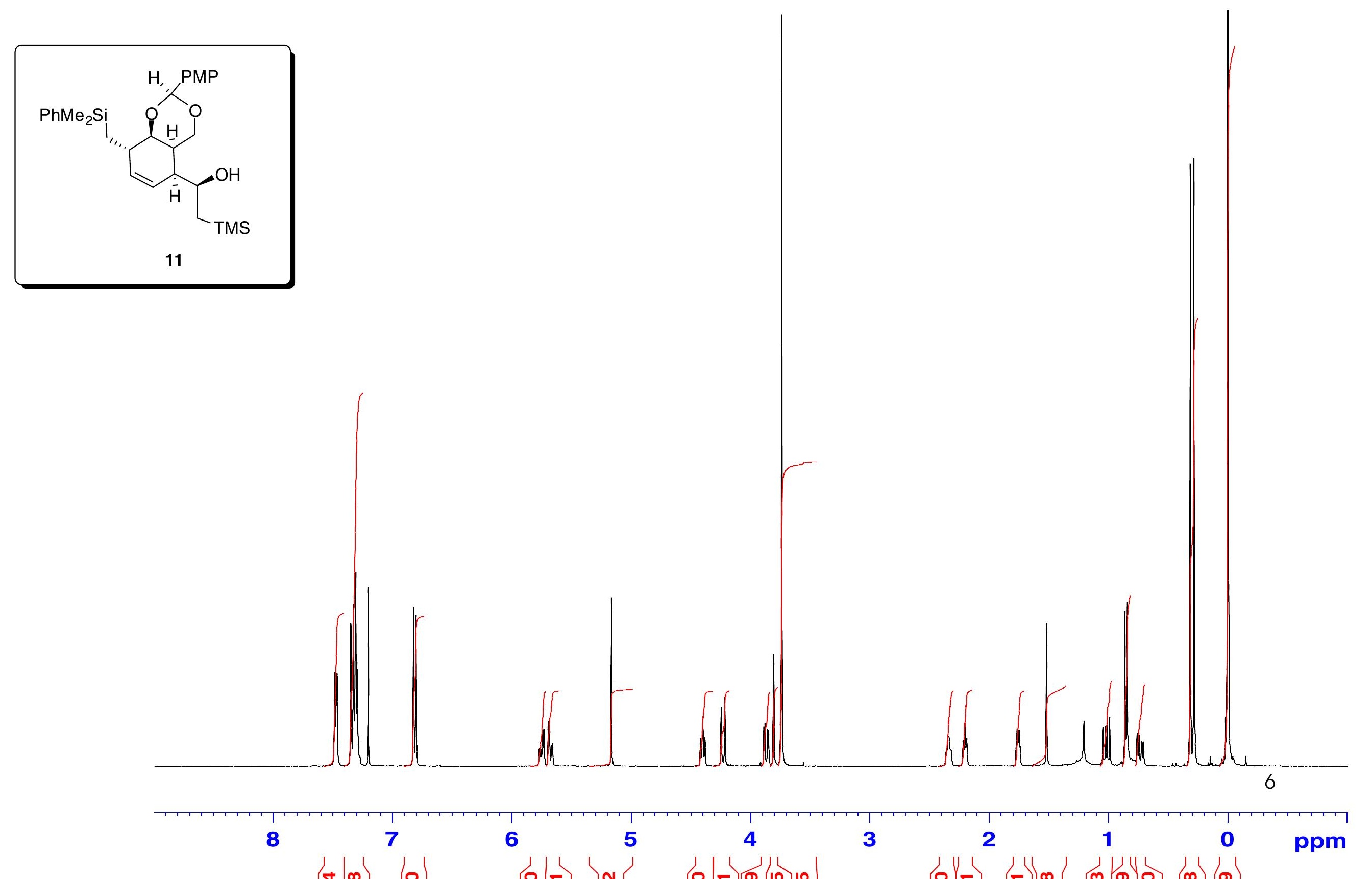

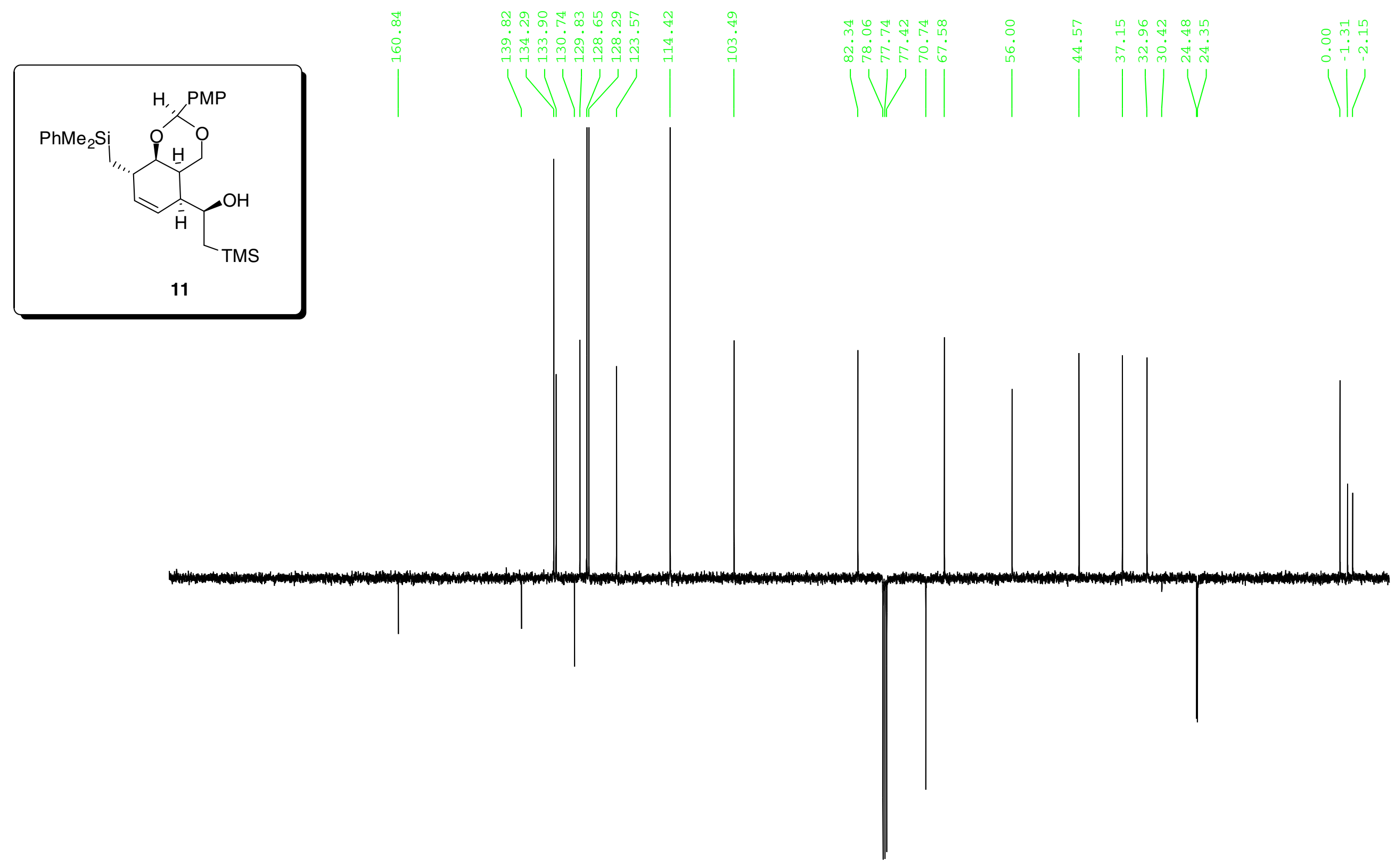

7

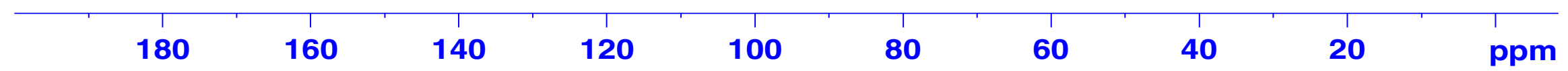




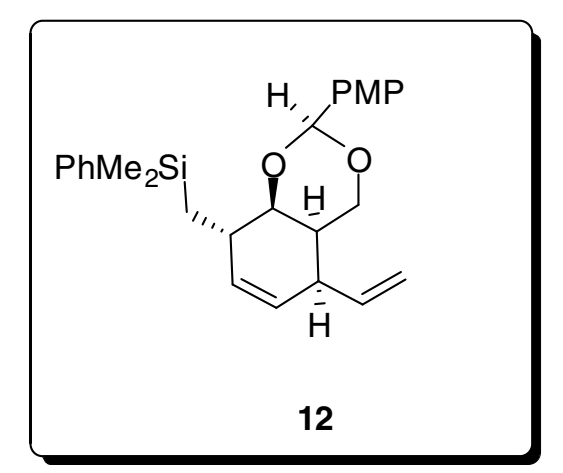

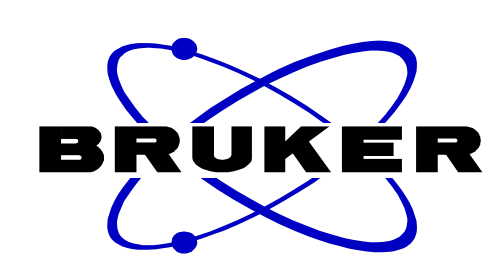
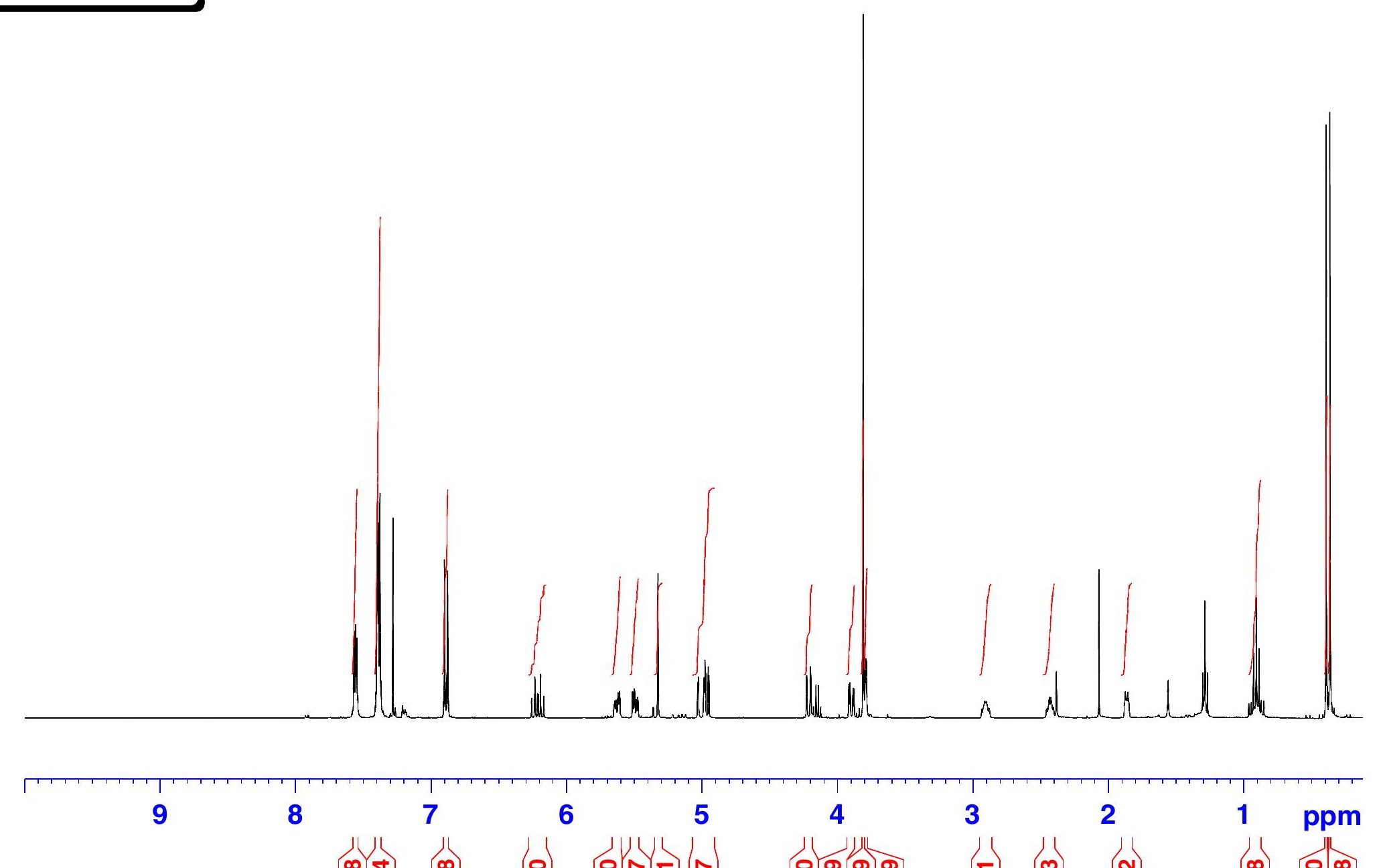


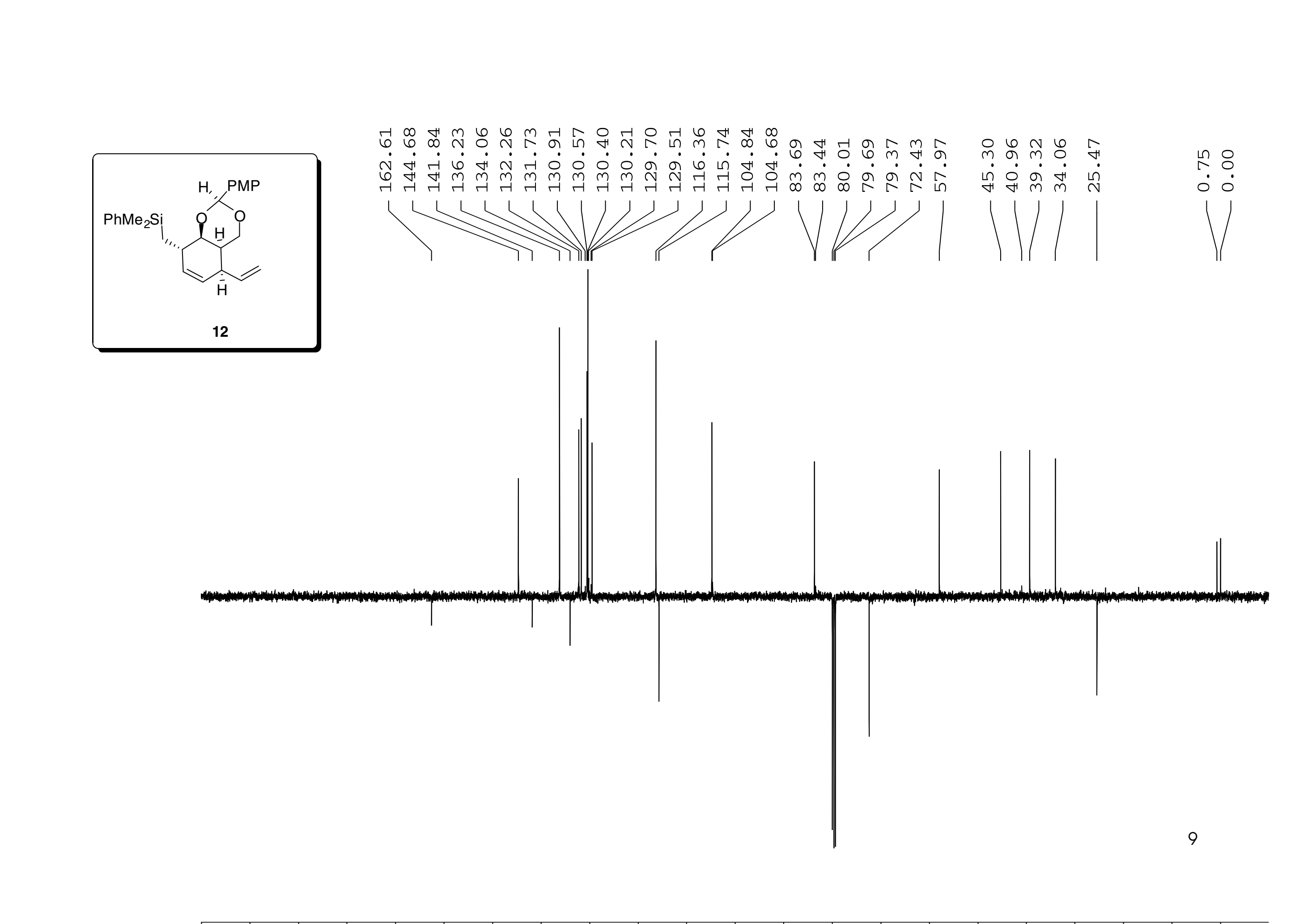



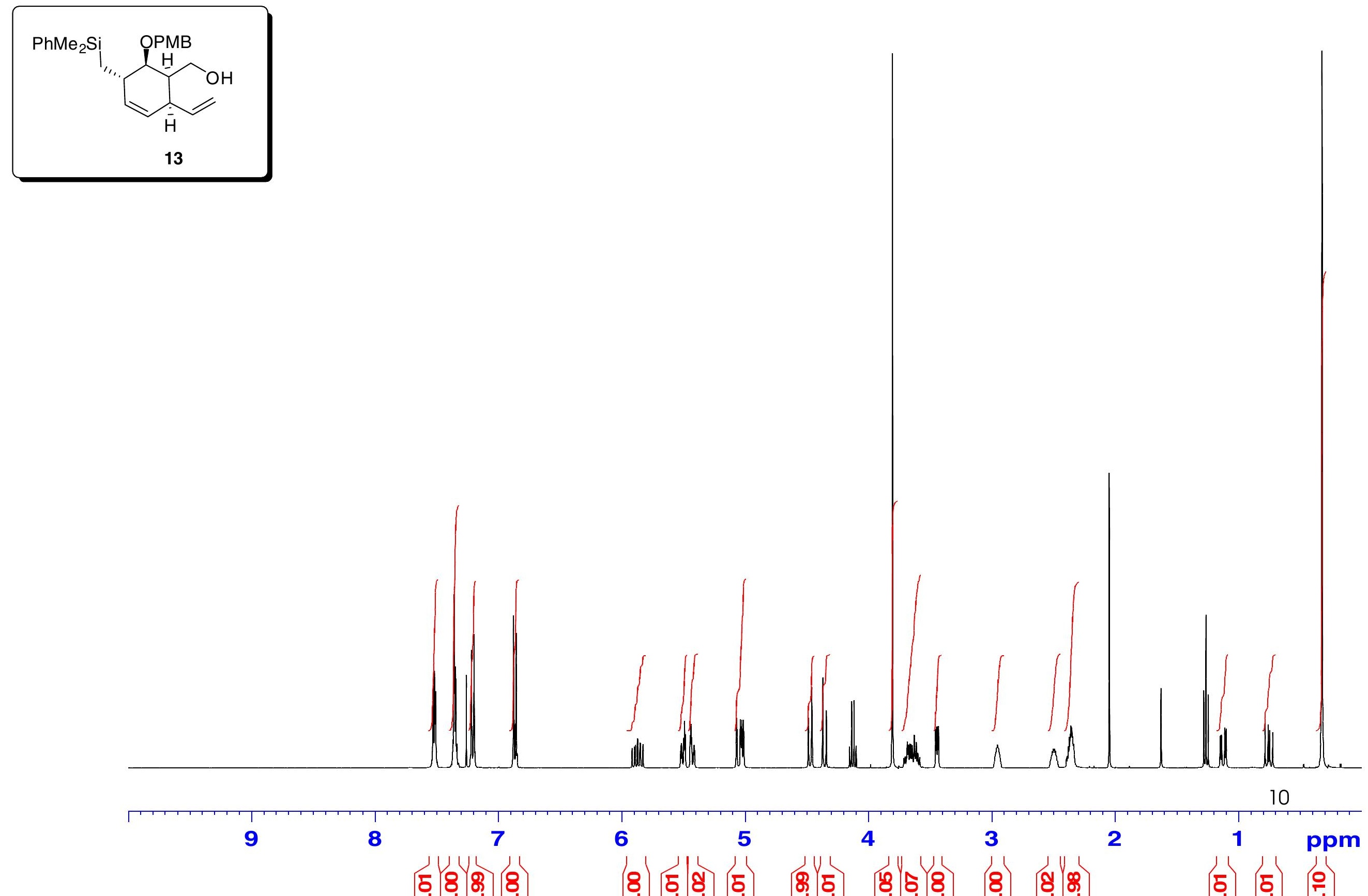


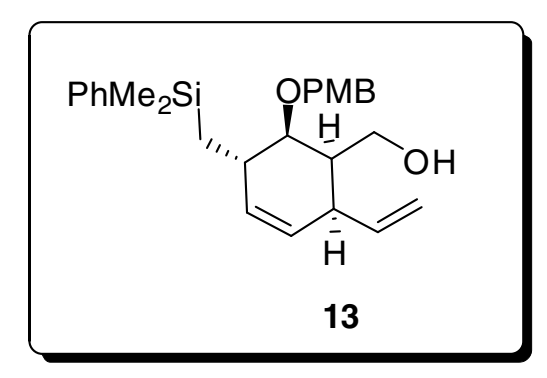

ᄀ 의

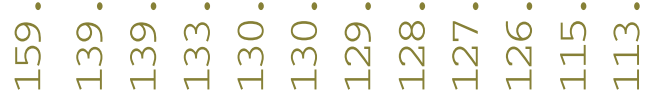

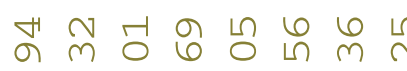

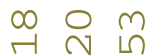

กำ

क

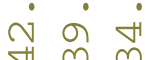

में

1111

$1 / 1 / 1 / 1$

$1 \mid 1$

$1 /$

$\stackrel{m}{m} \stackrel{m}{\sim}$

में
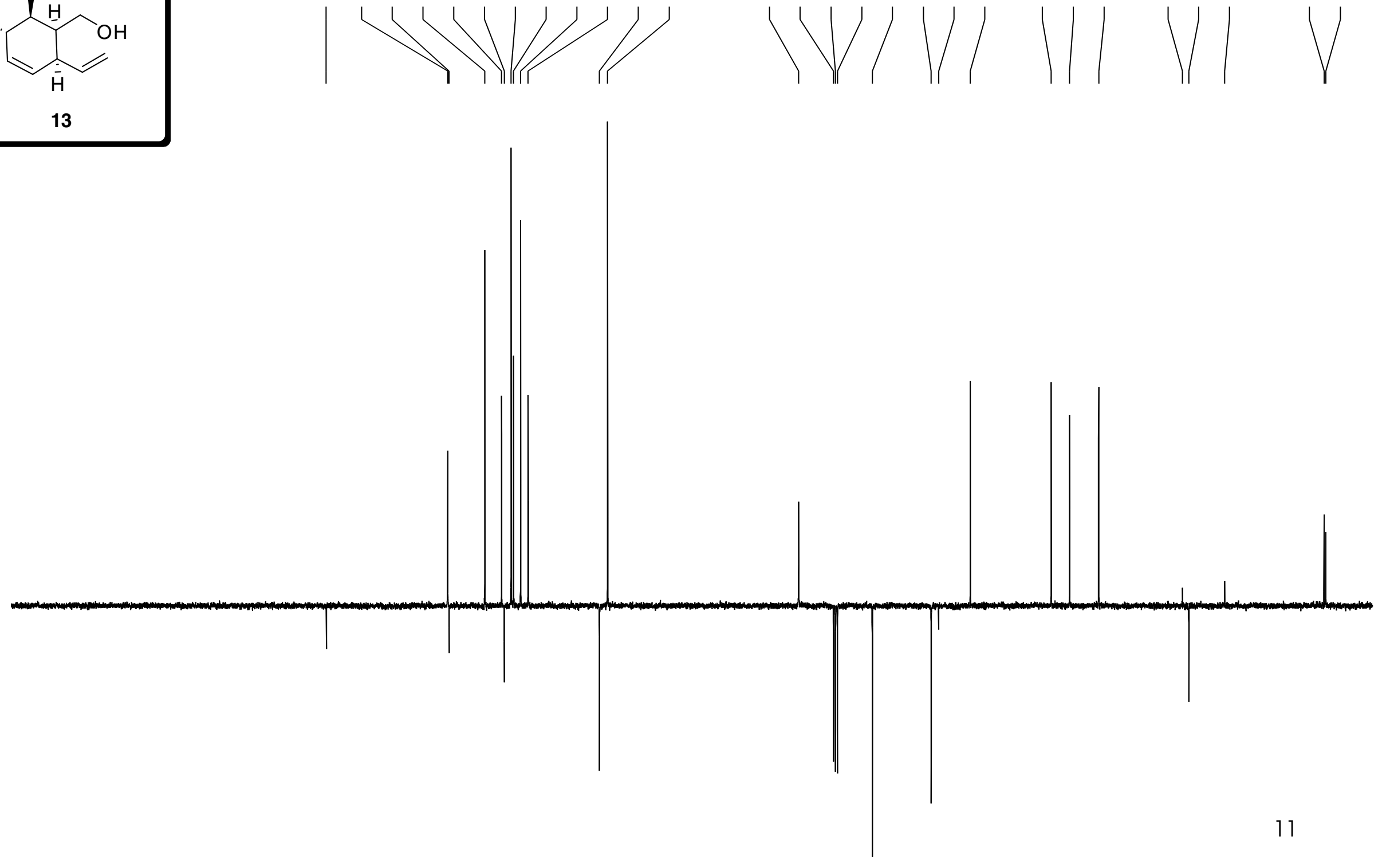

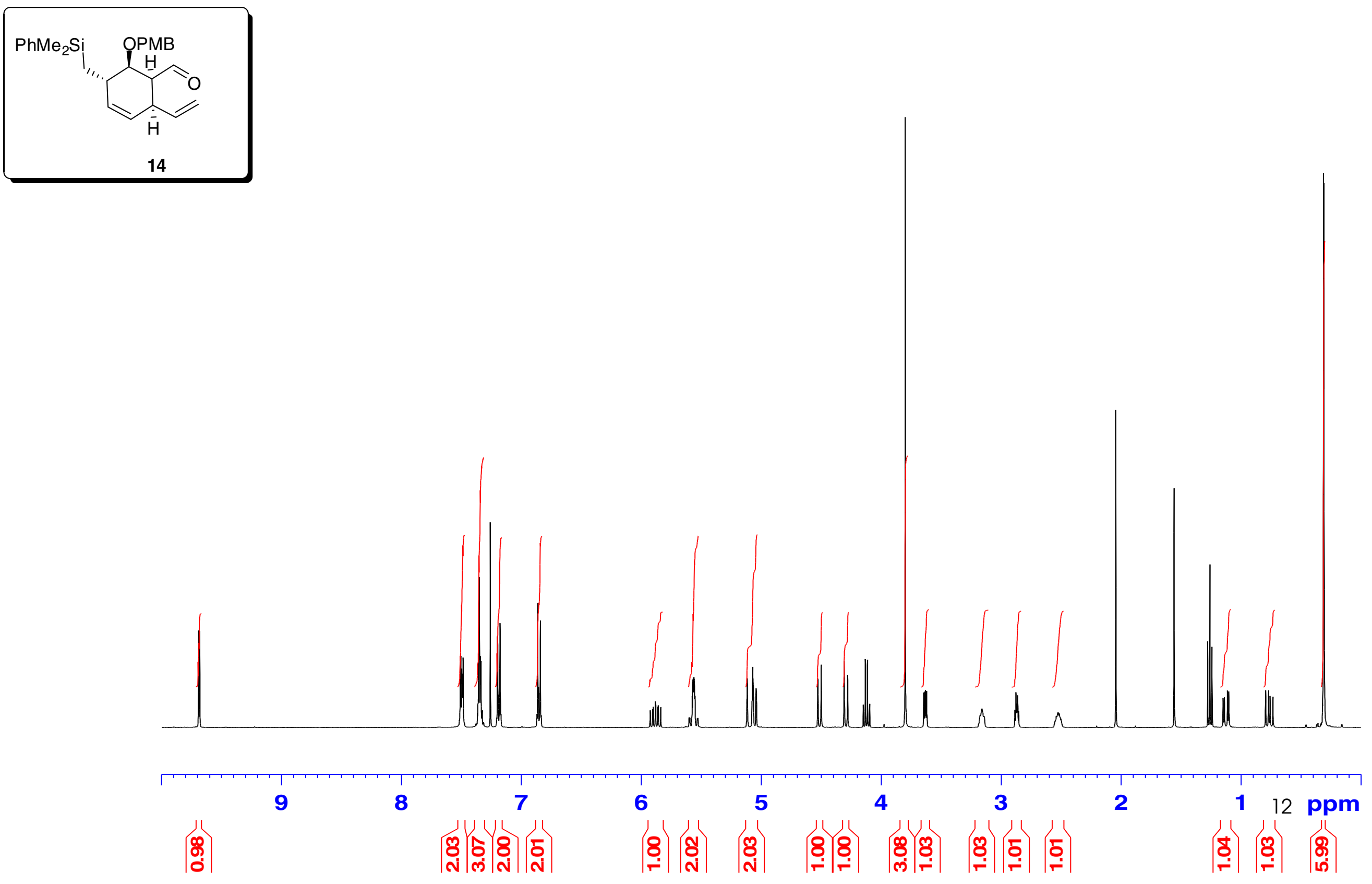


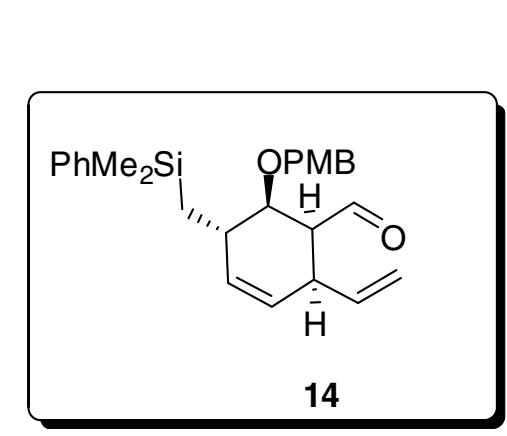

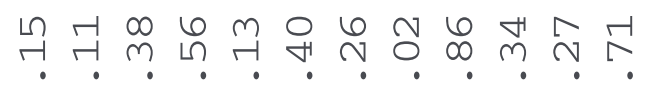

$\dot{\circ} \dot{0} \dot{m} \dot{m} \dot{\circ} \dot{\circ} \dot{\circ} \dot{0} \dot{0} \dot{m}$

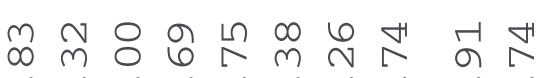

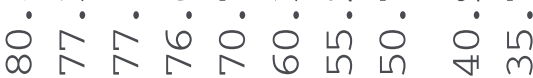

ก

ำ

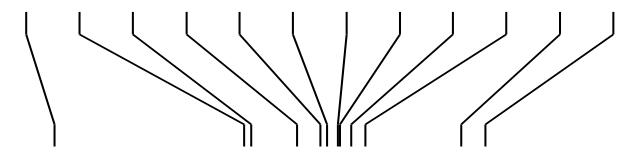

> $|/| 1 \mid$

નુ

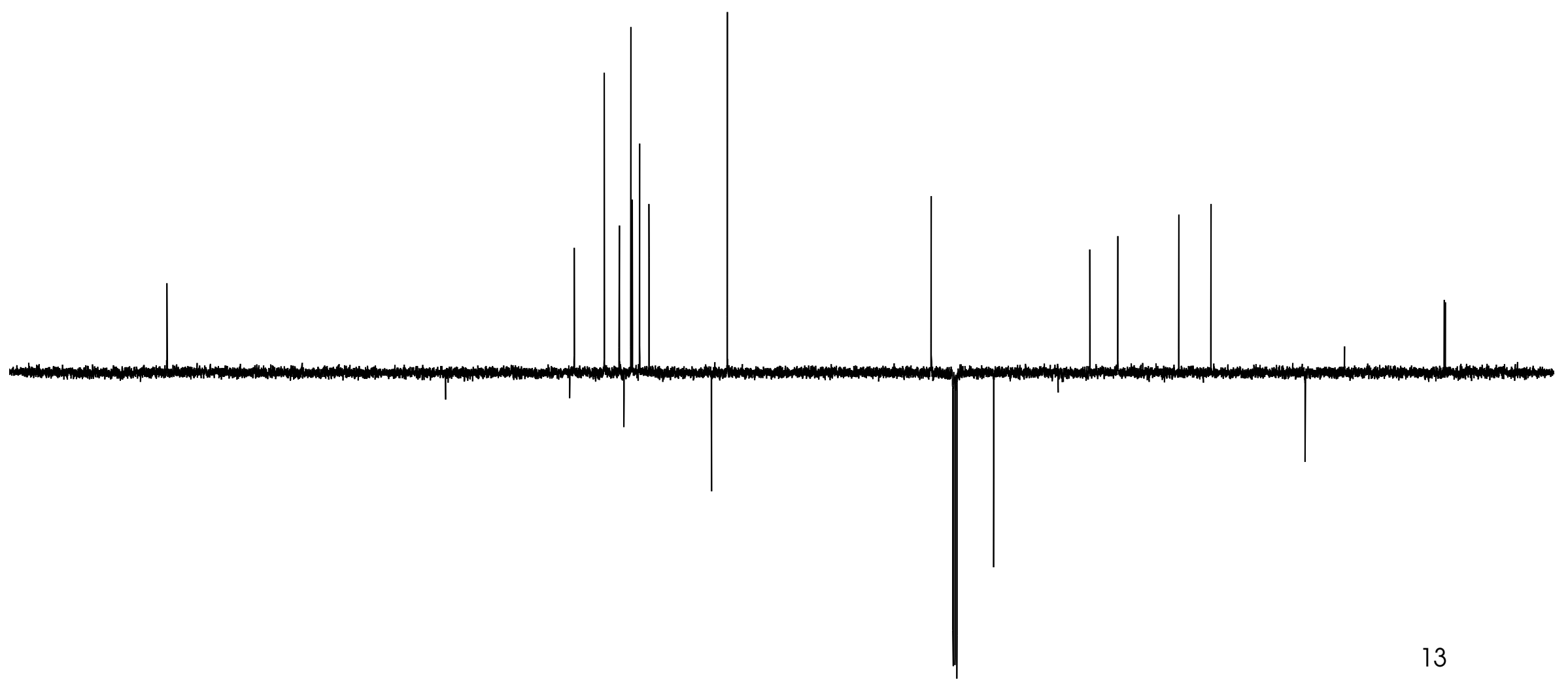



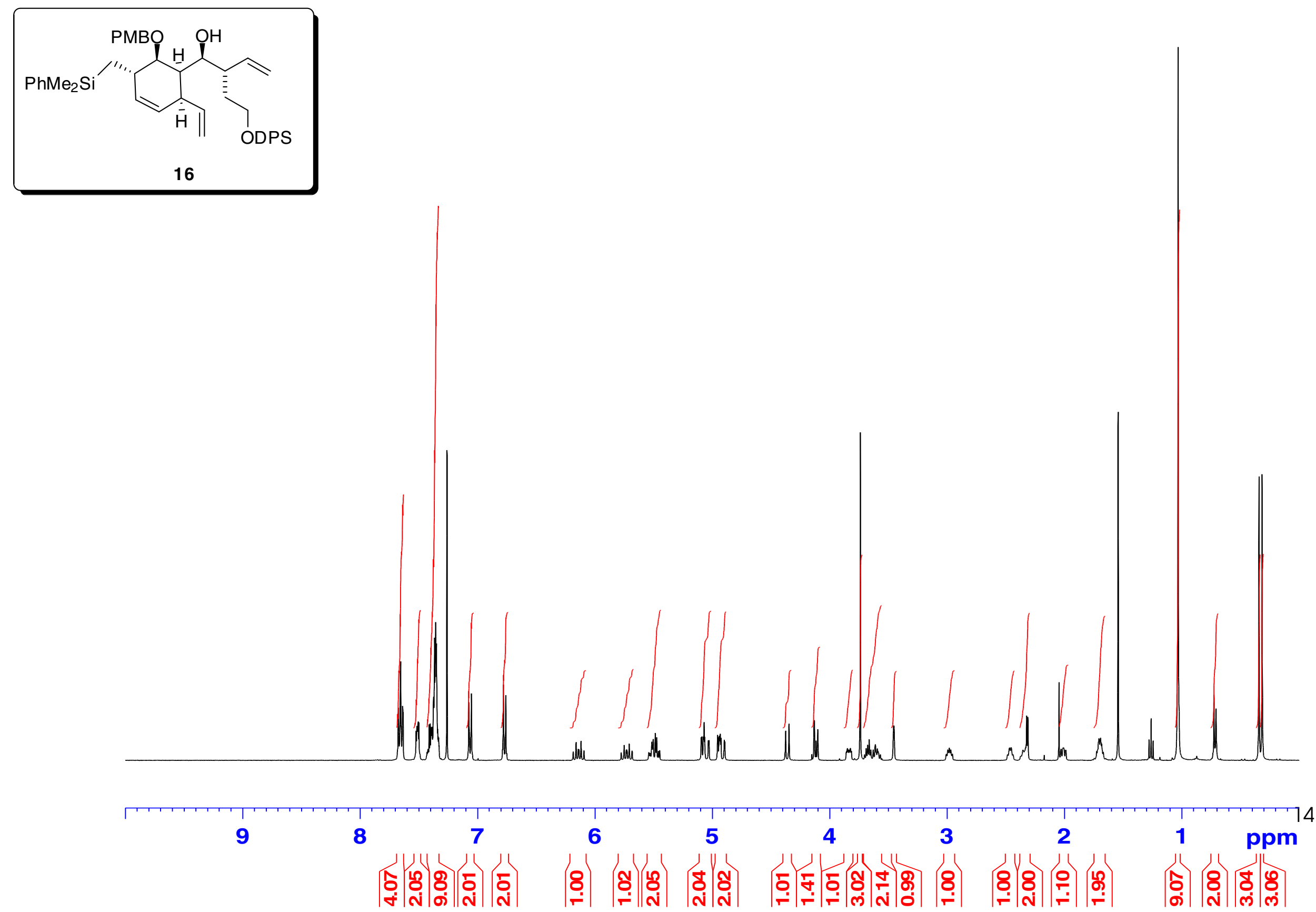
の̆

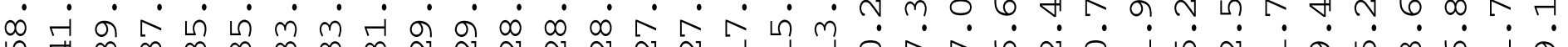

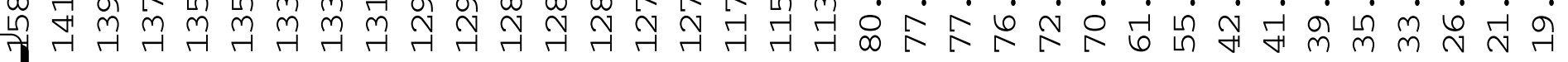
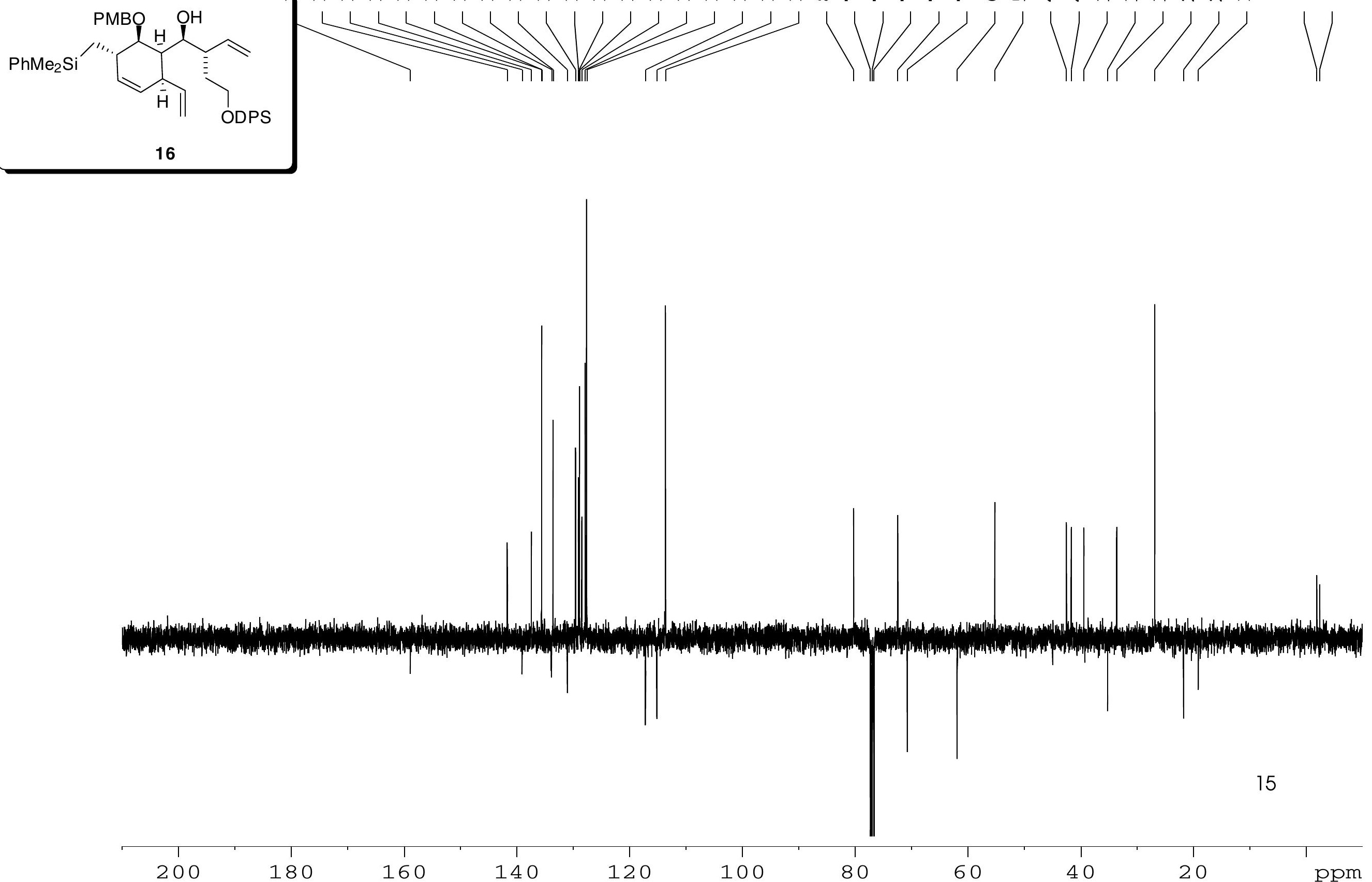

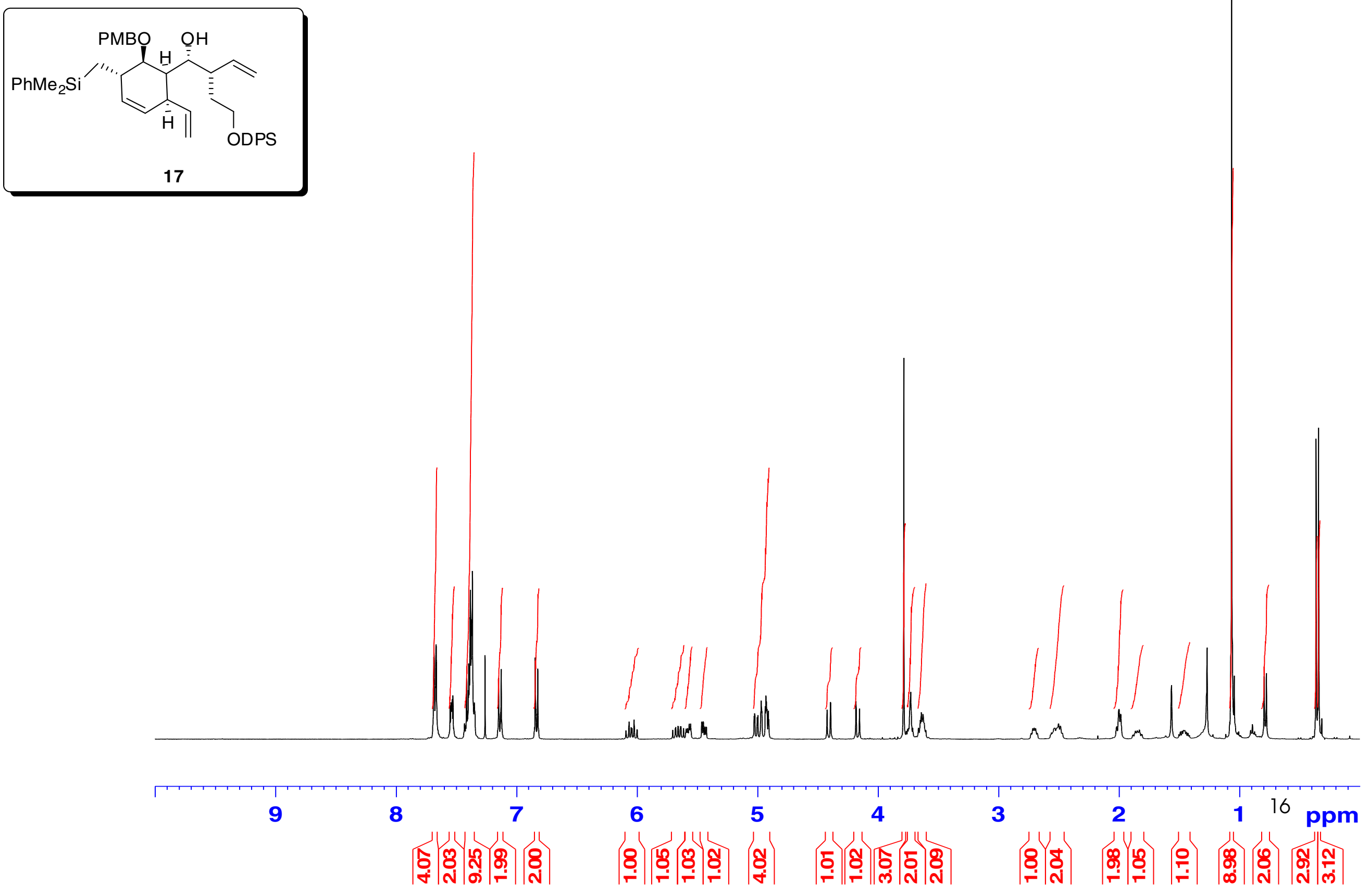


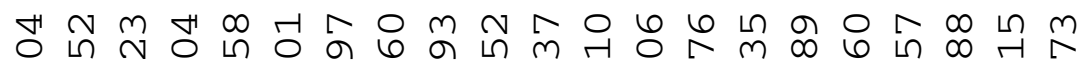

1

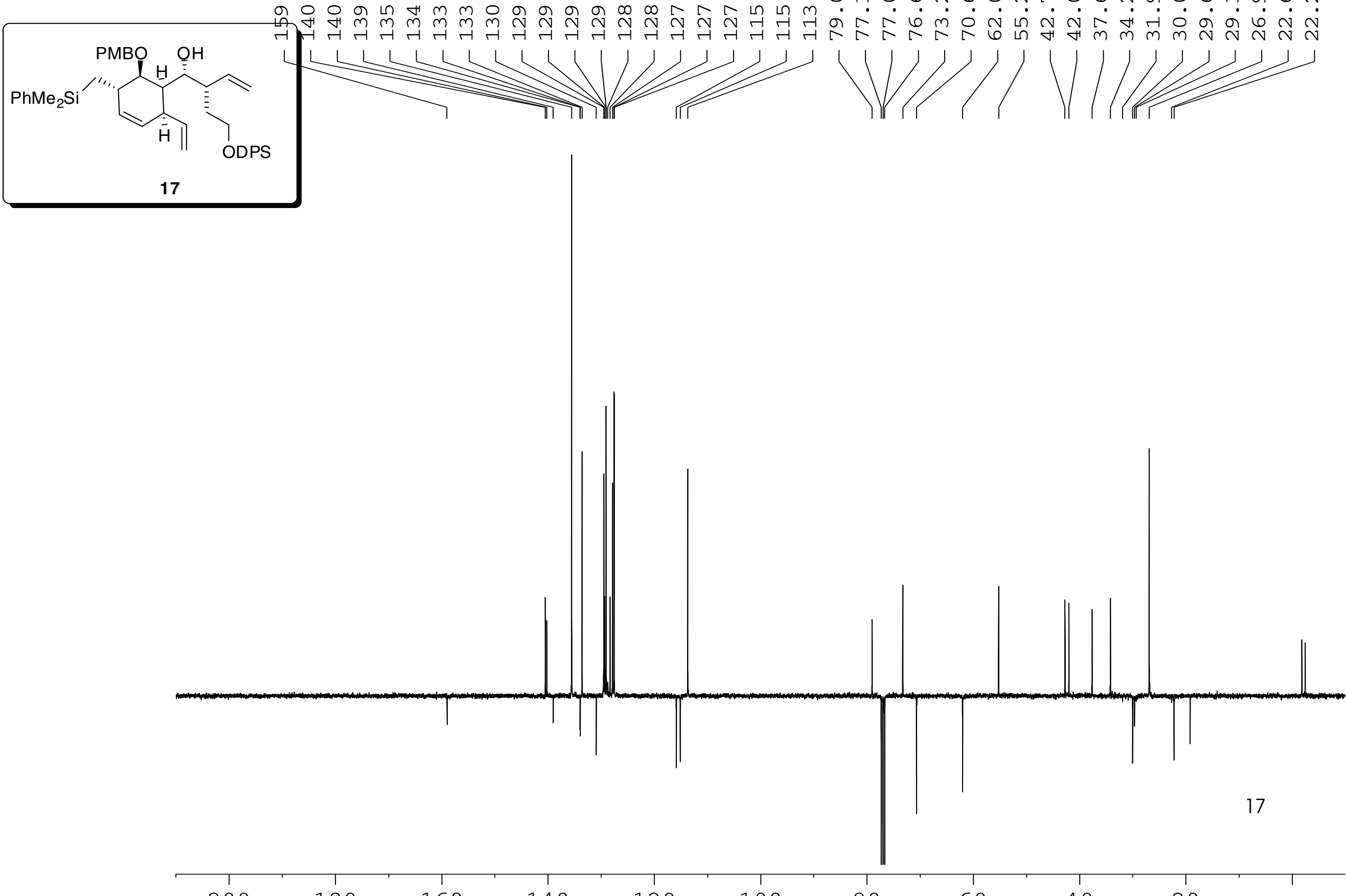



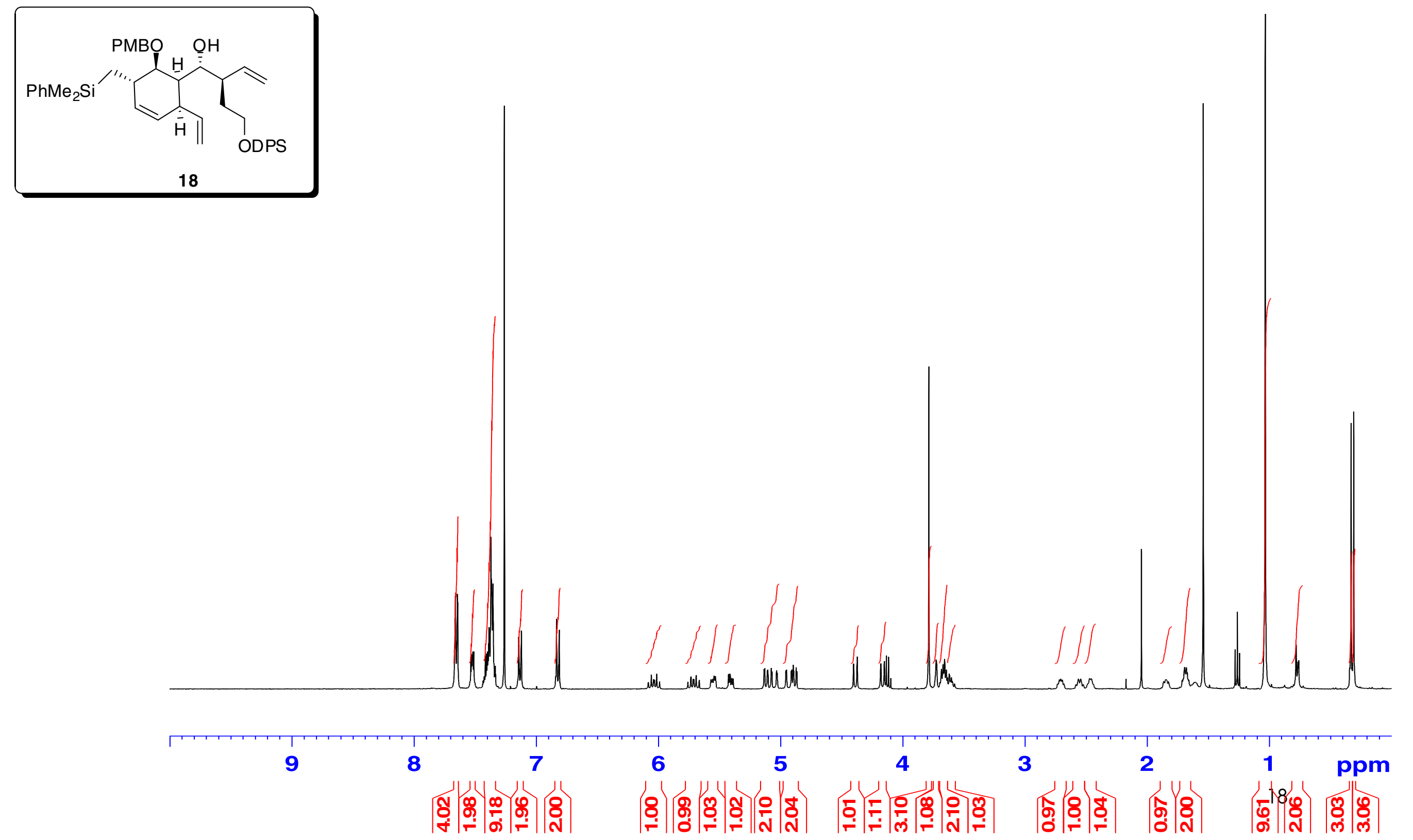


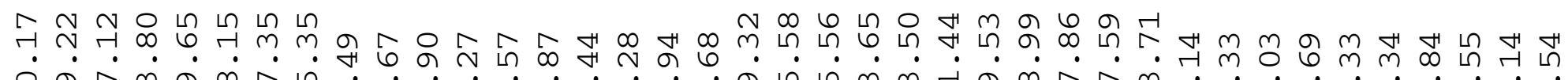

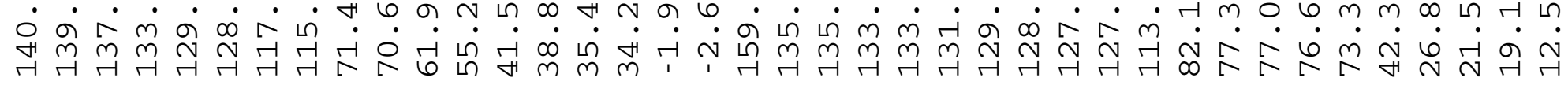

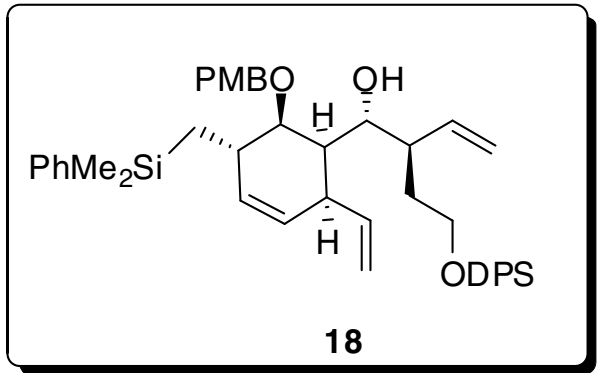

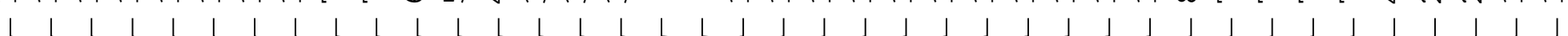

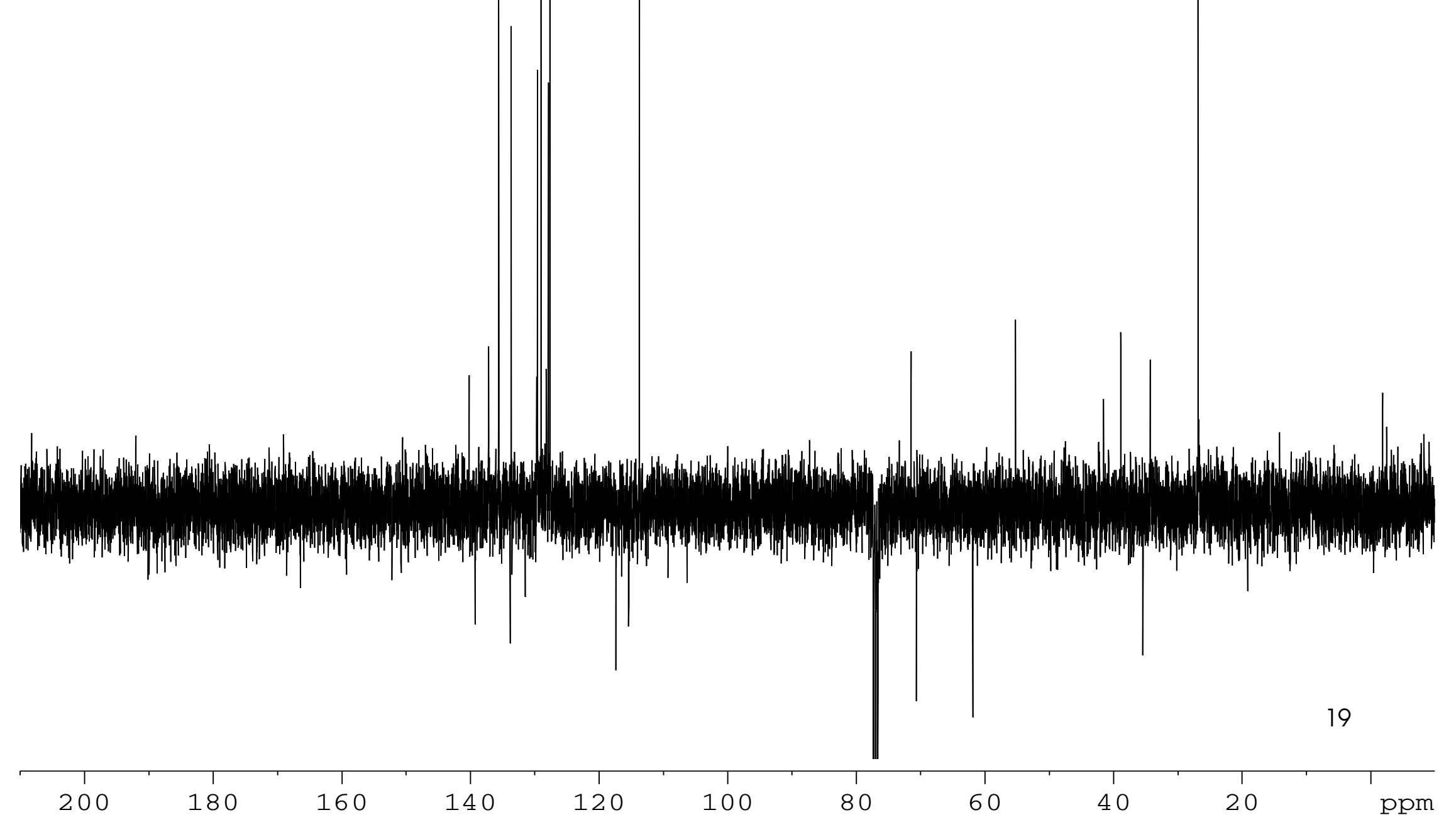



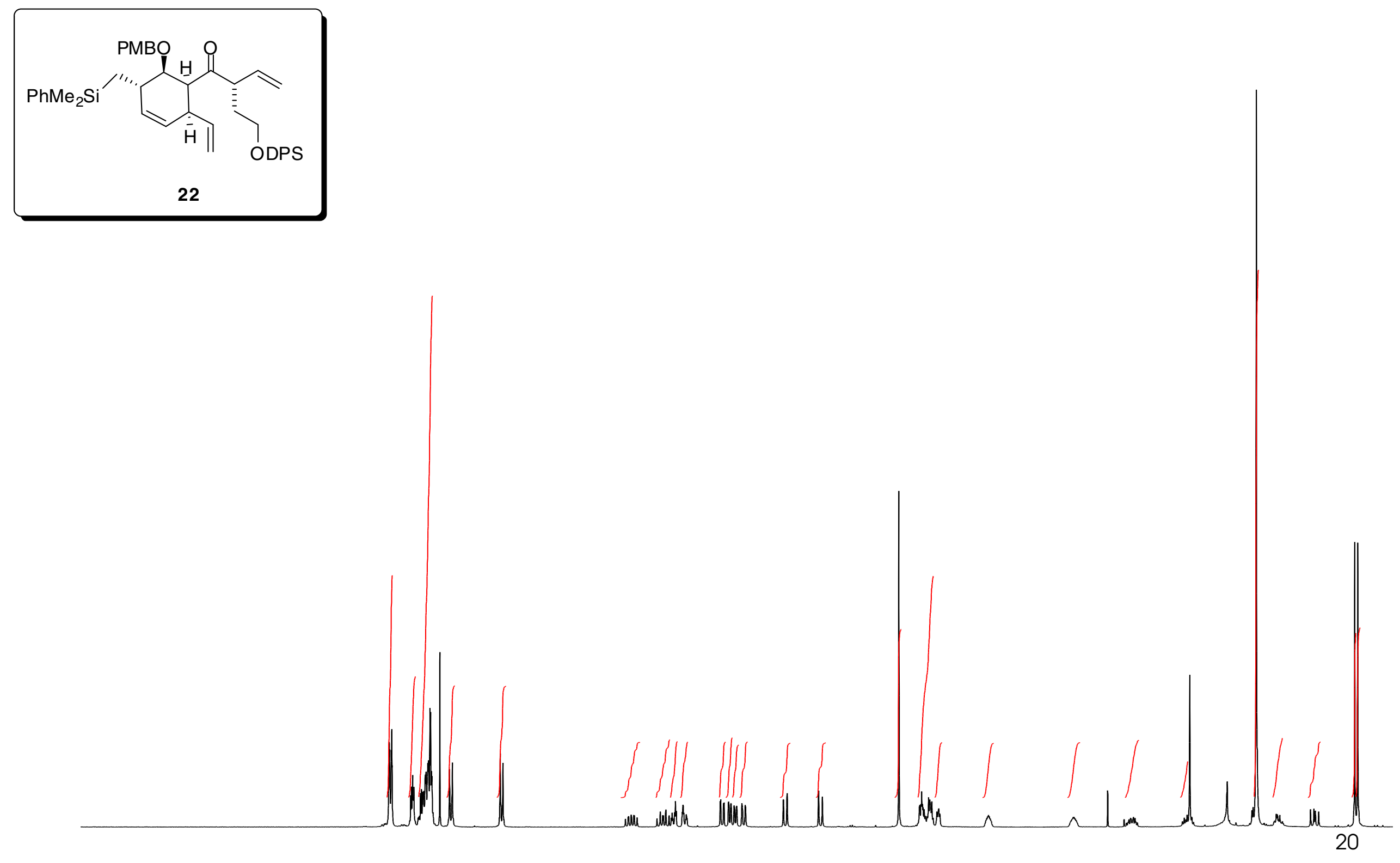

$\begin{array}{lllllllllllllllllll}9.5 & 9.0 & 8.5 & 8.0 & 7.5 & 7.0 & 6.5 & 6.0 & 5.5 & 5.0 & 4.5 & 4.0 & 3.5 & 3.0 & 2.5 & 2.0 & 1.5 & 1.0 & \mathrm{ppm}\end{array}$

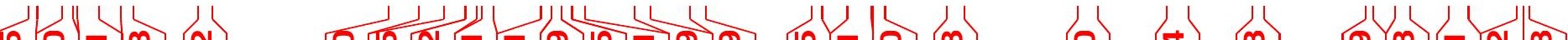




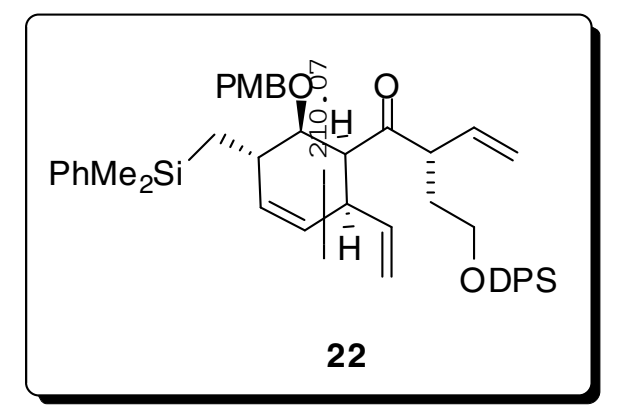

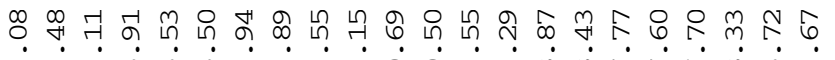

今్

뜬ำ

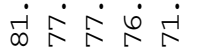

ำ

WI

ठิ

$1 / 1|1|$

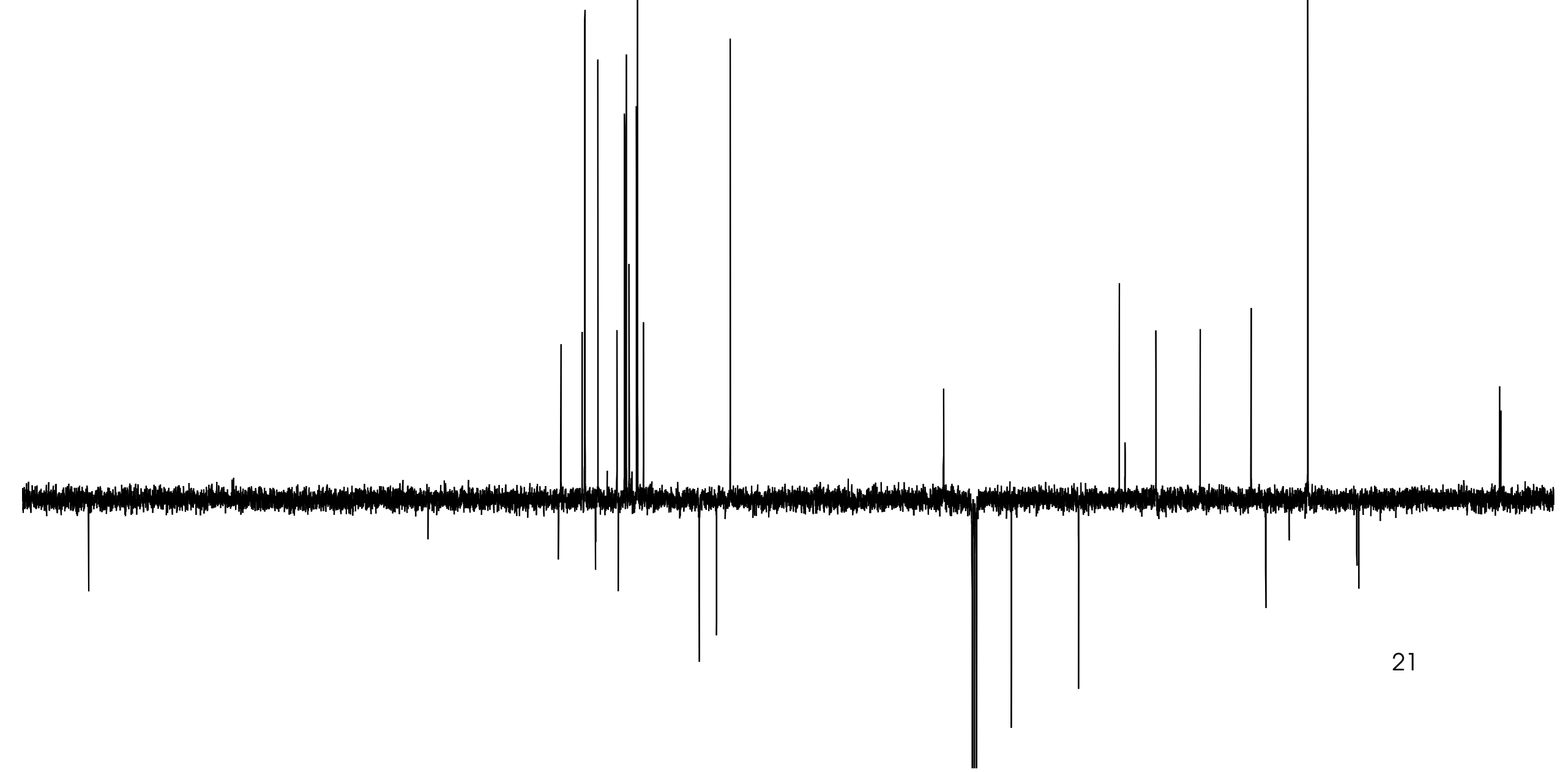



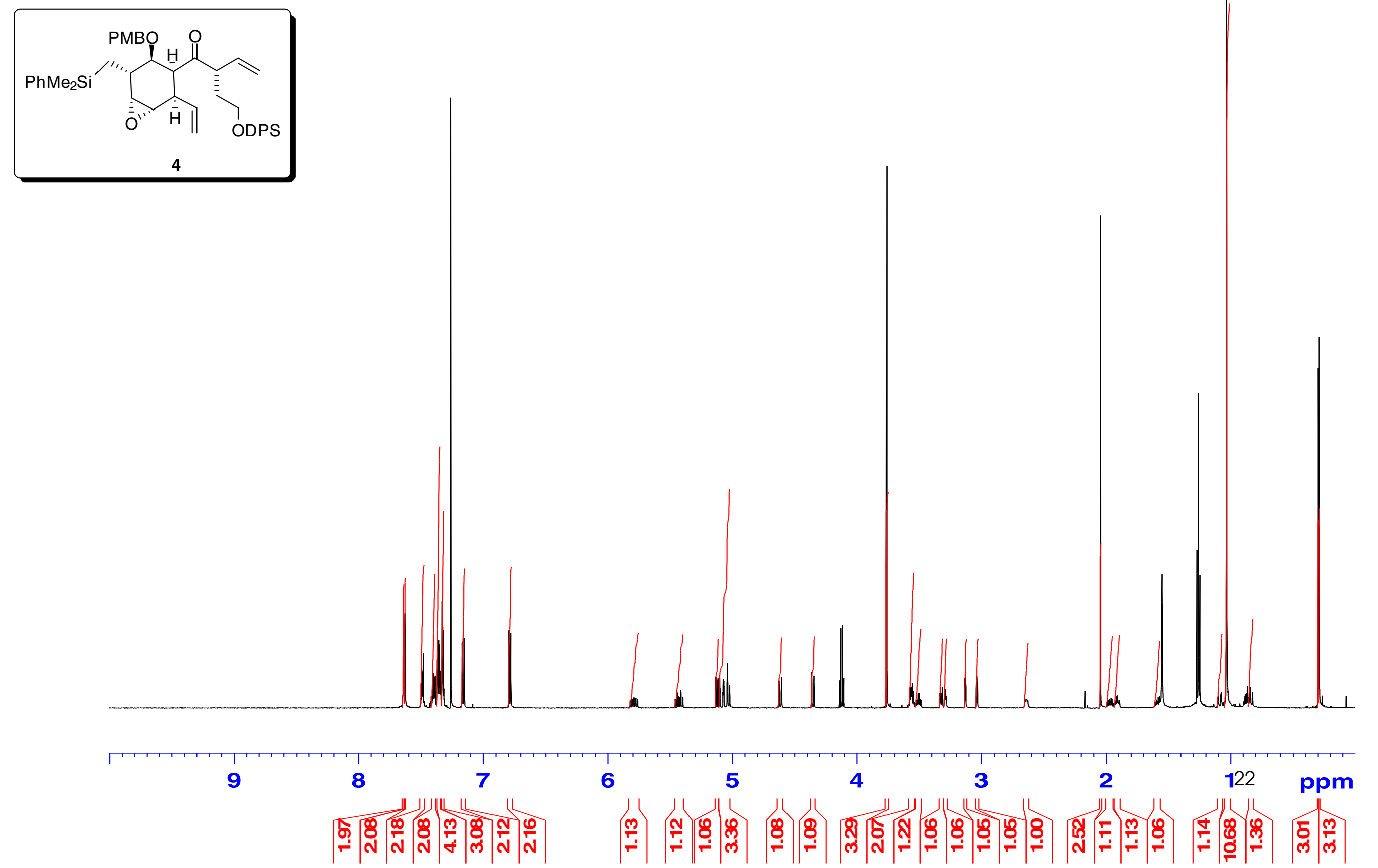


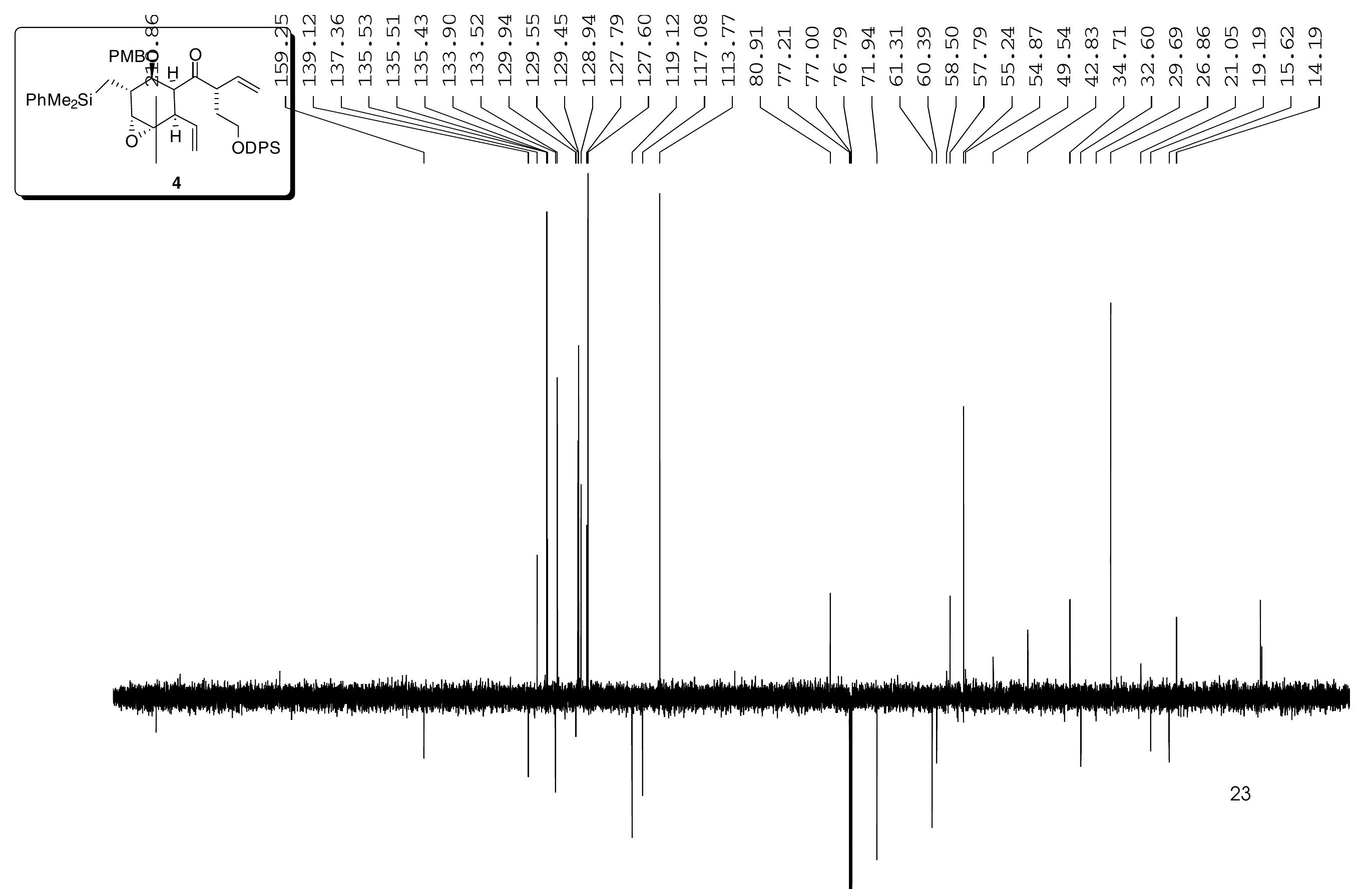



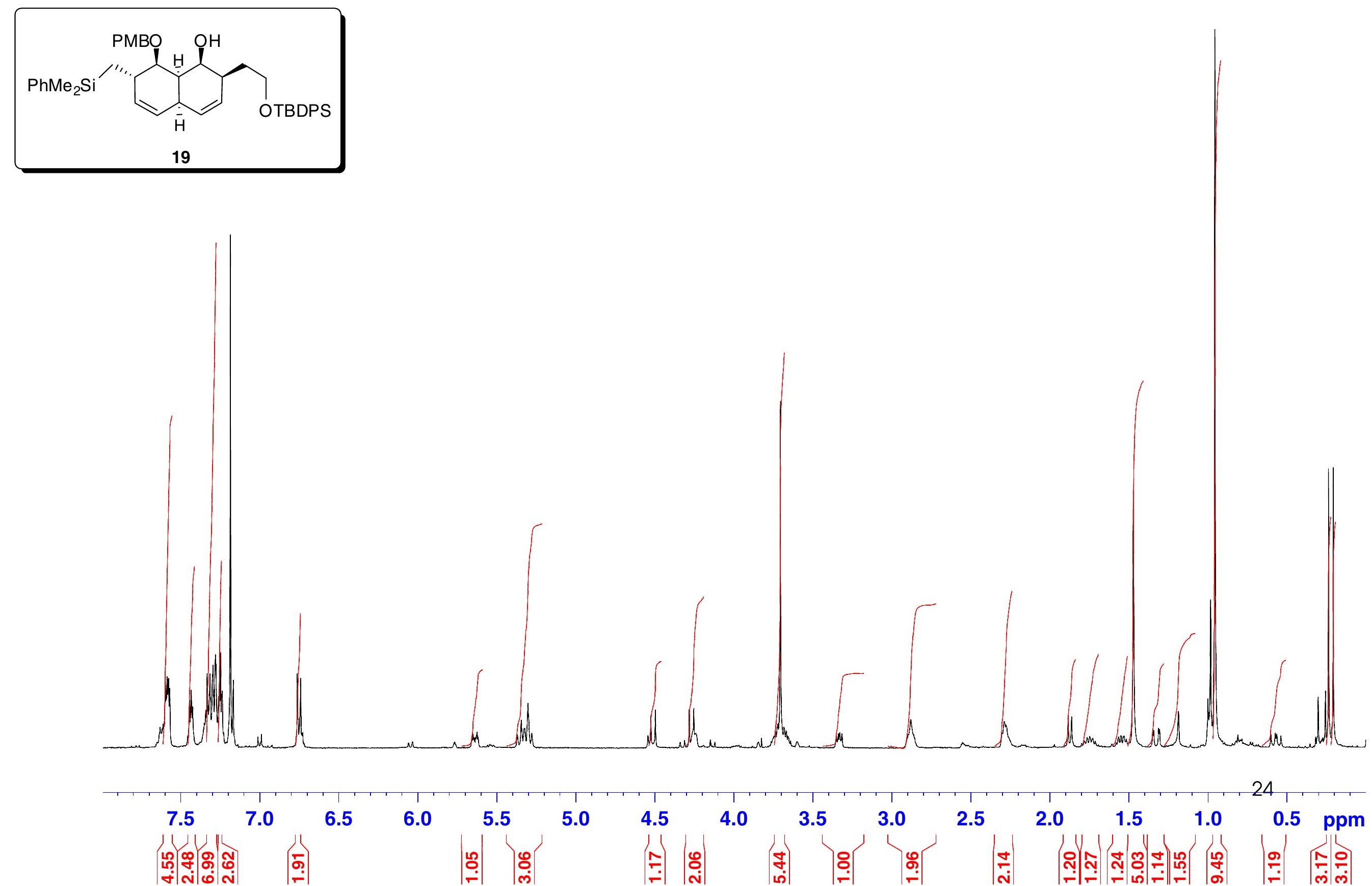


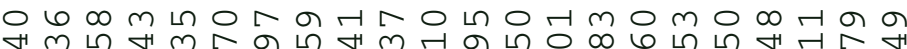

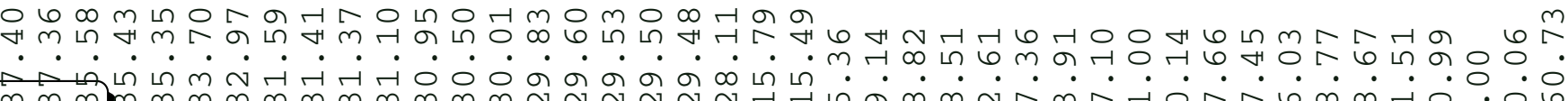
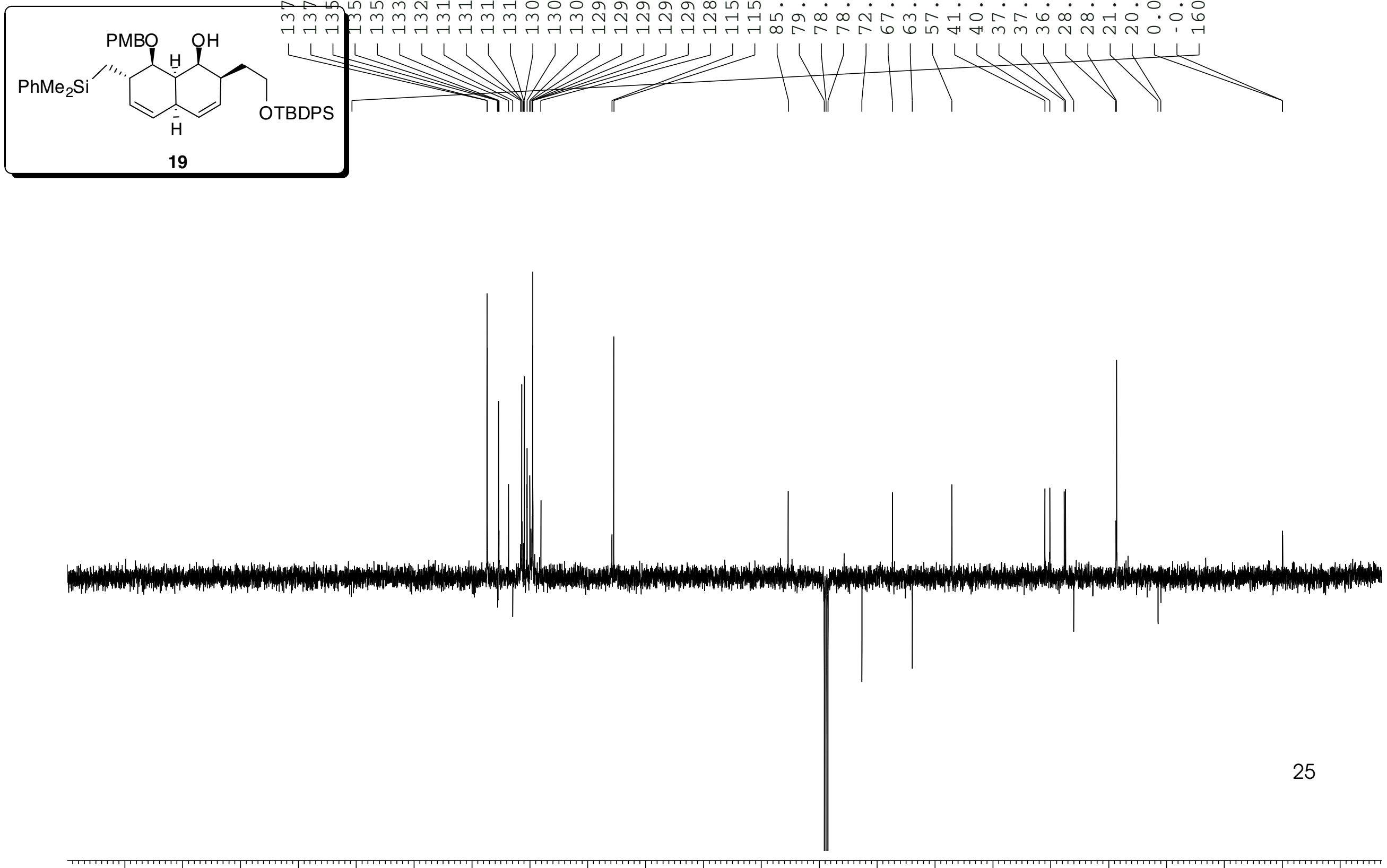

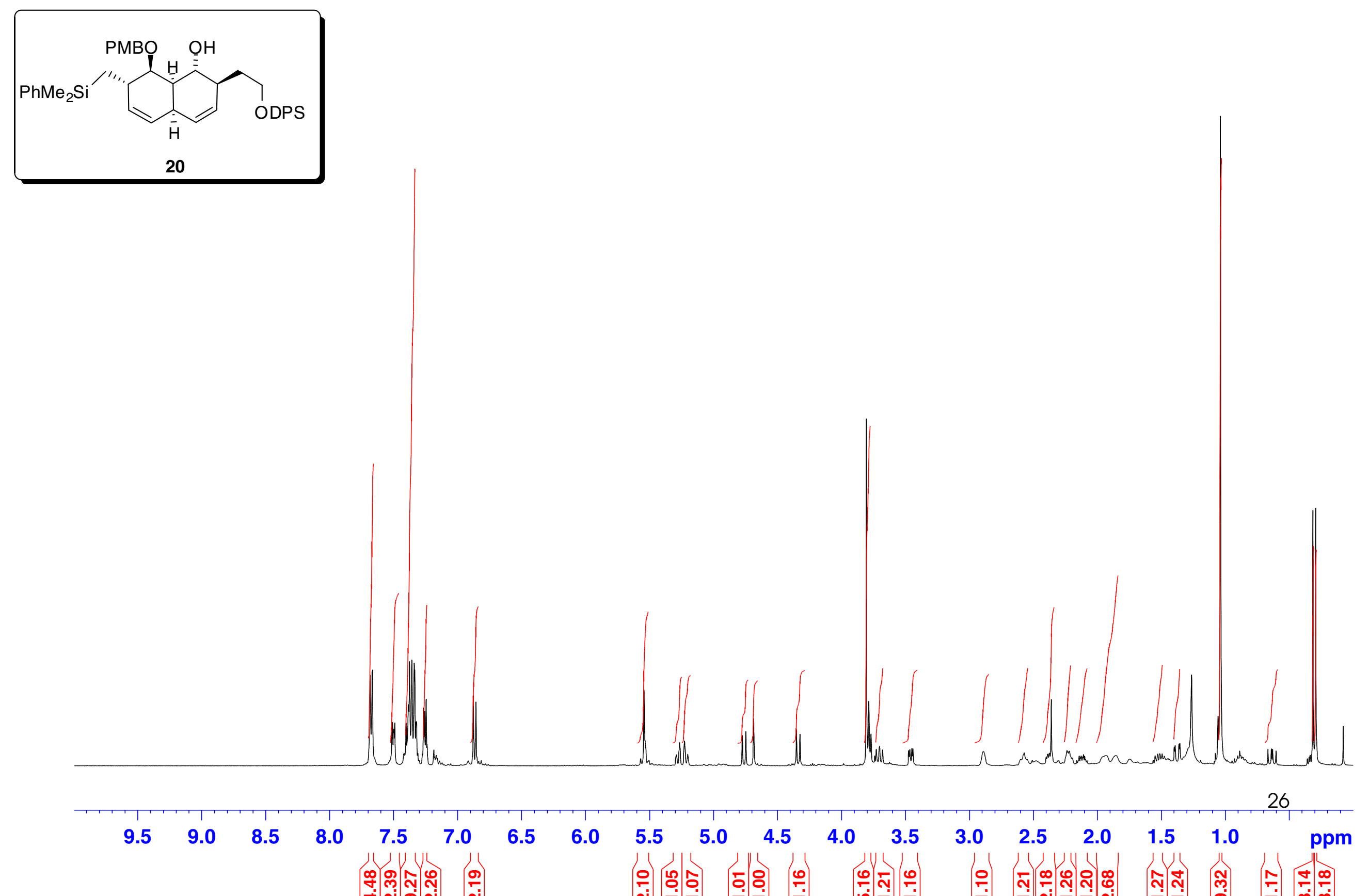


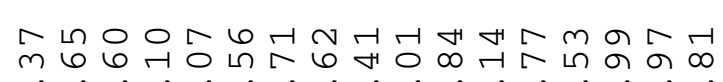

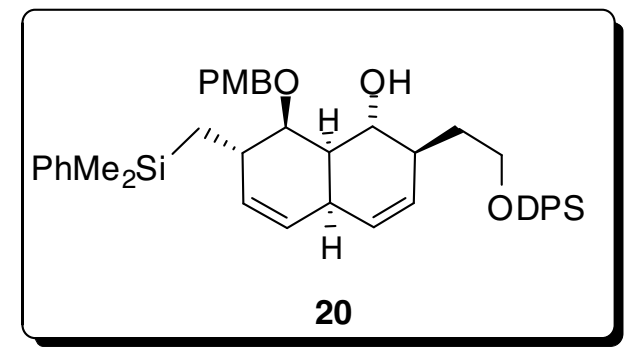

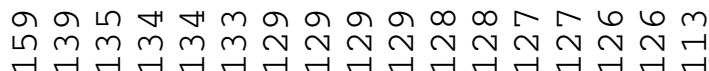

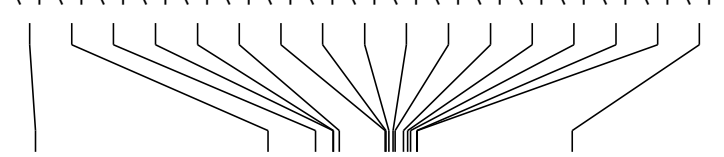

๙

ம்

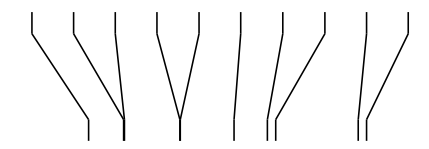

ดั
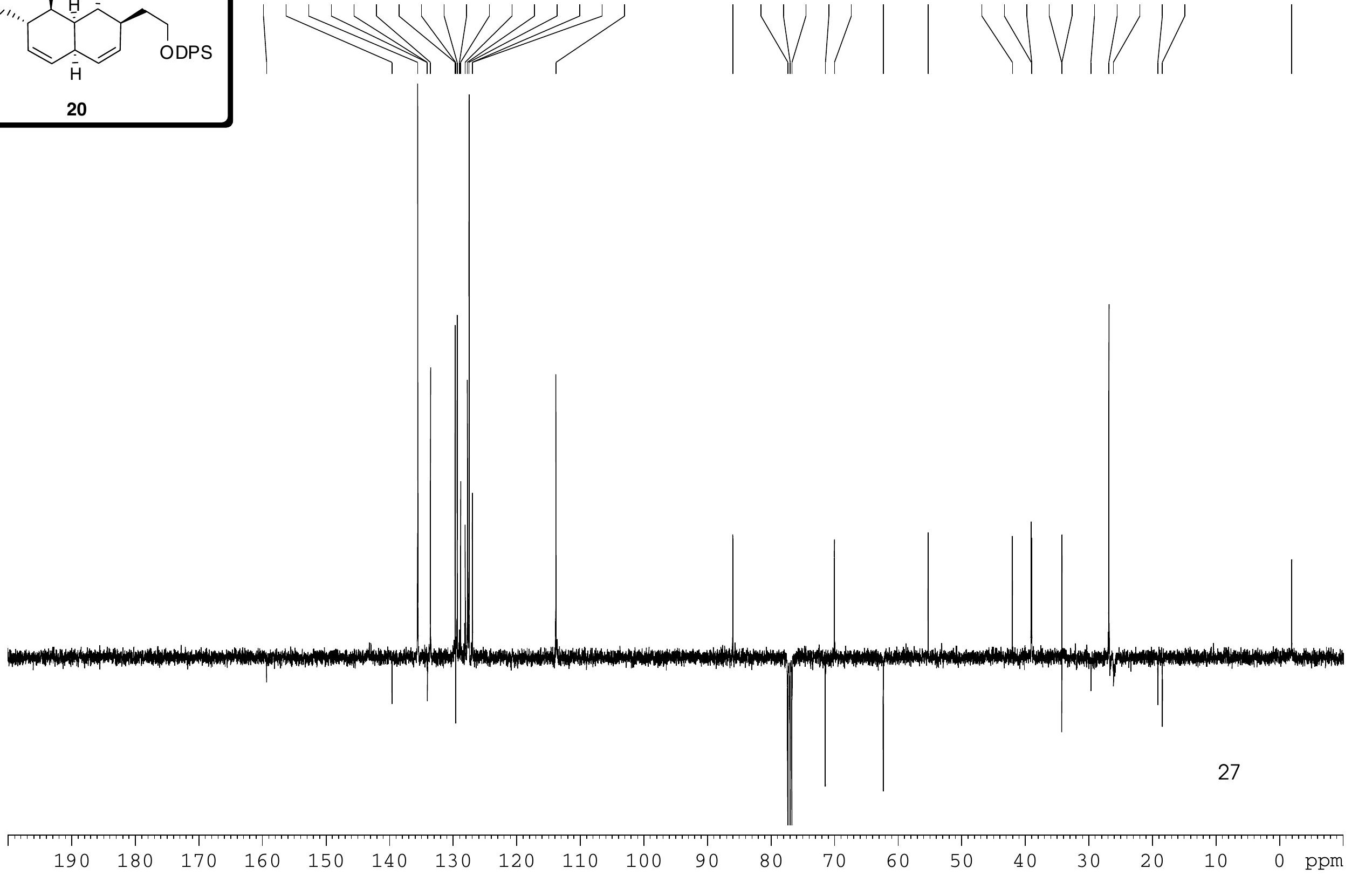

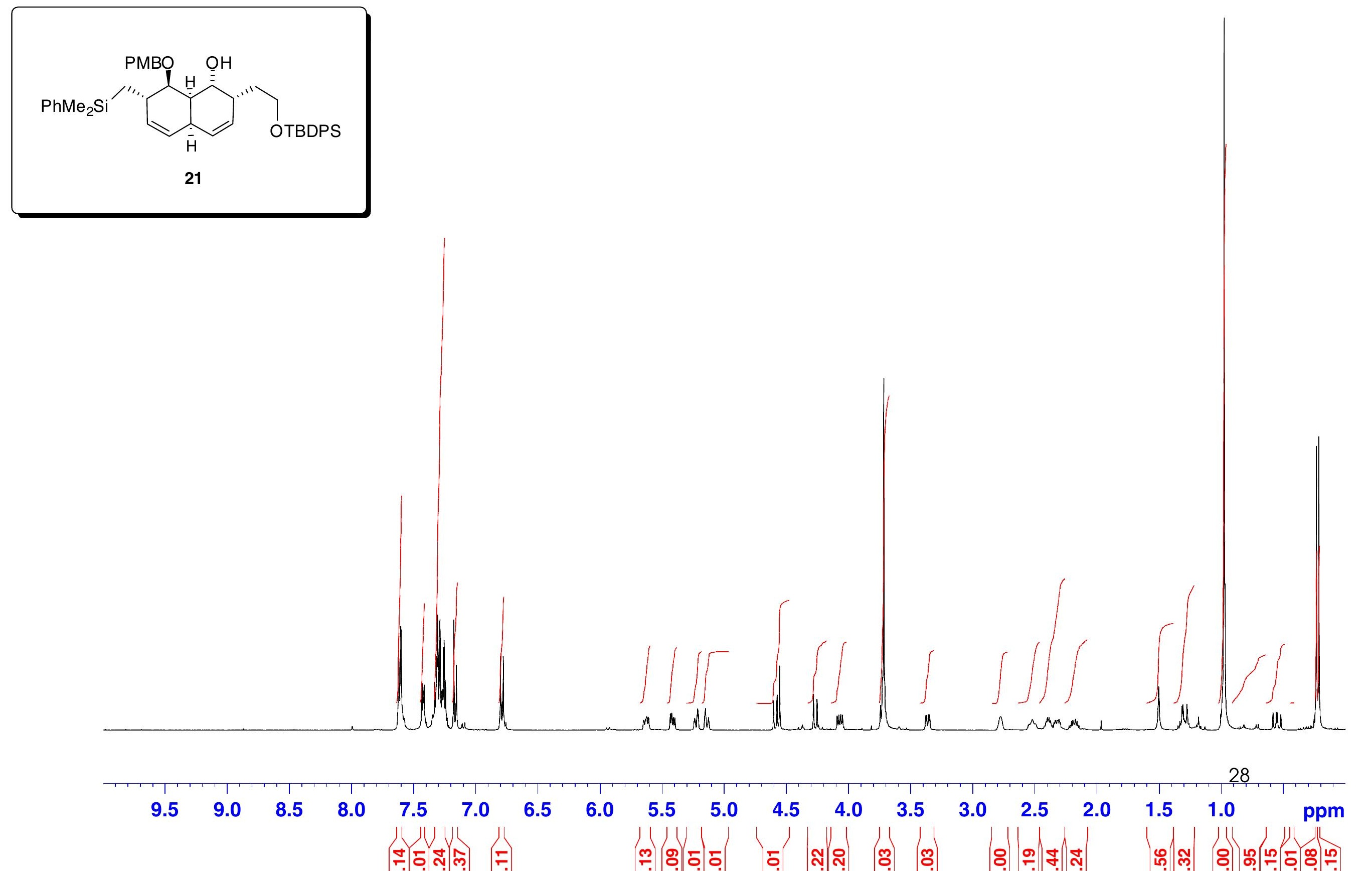


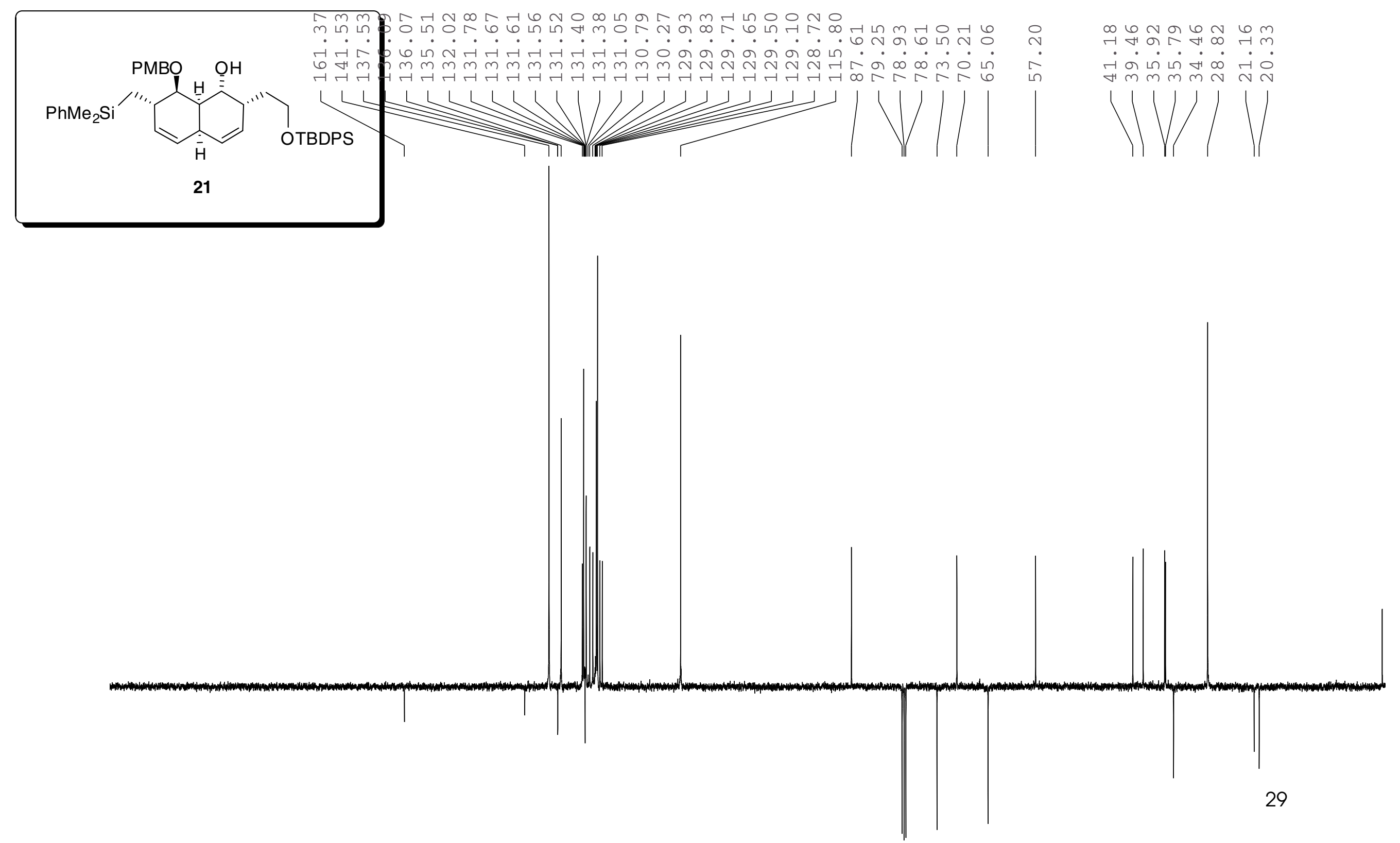



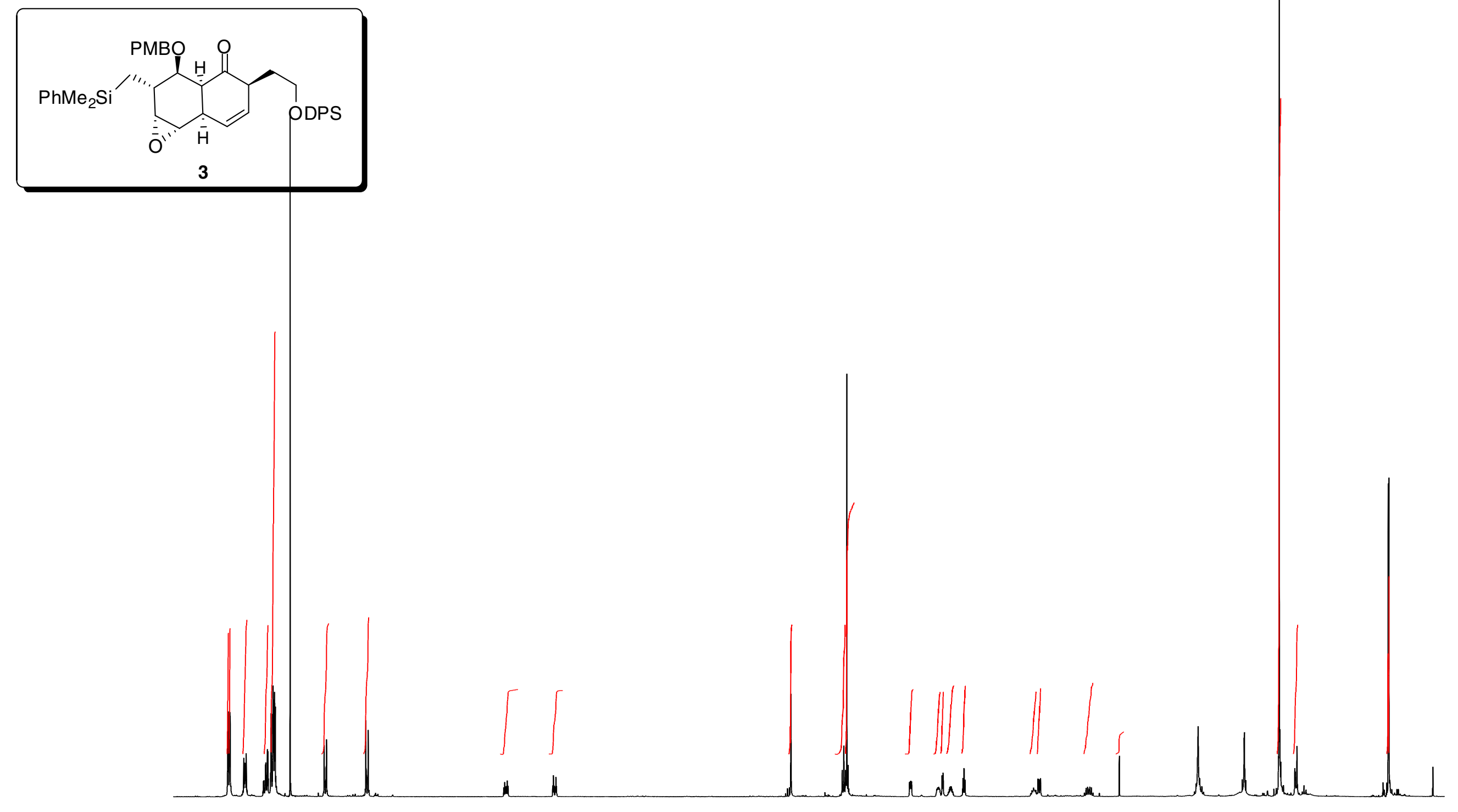

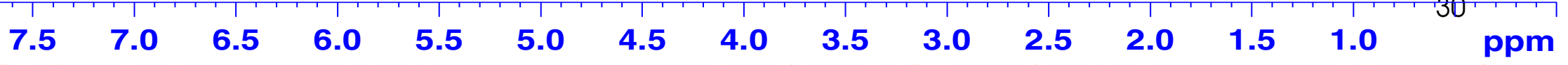

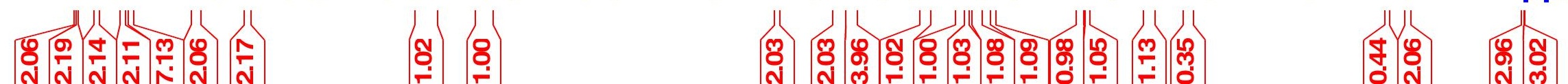




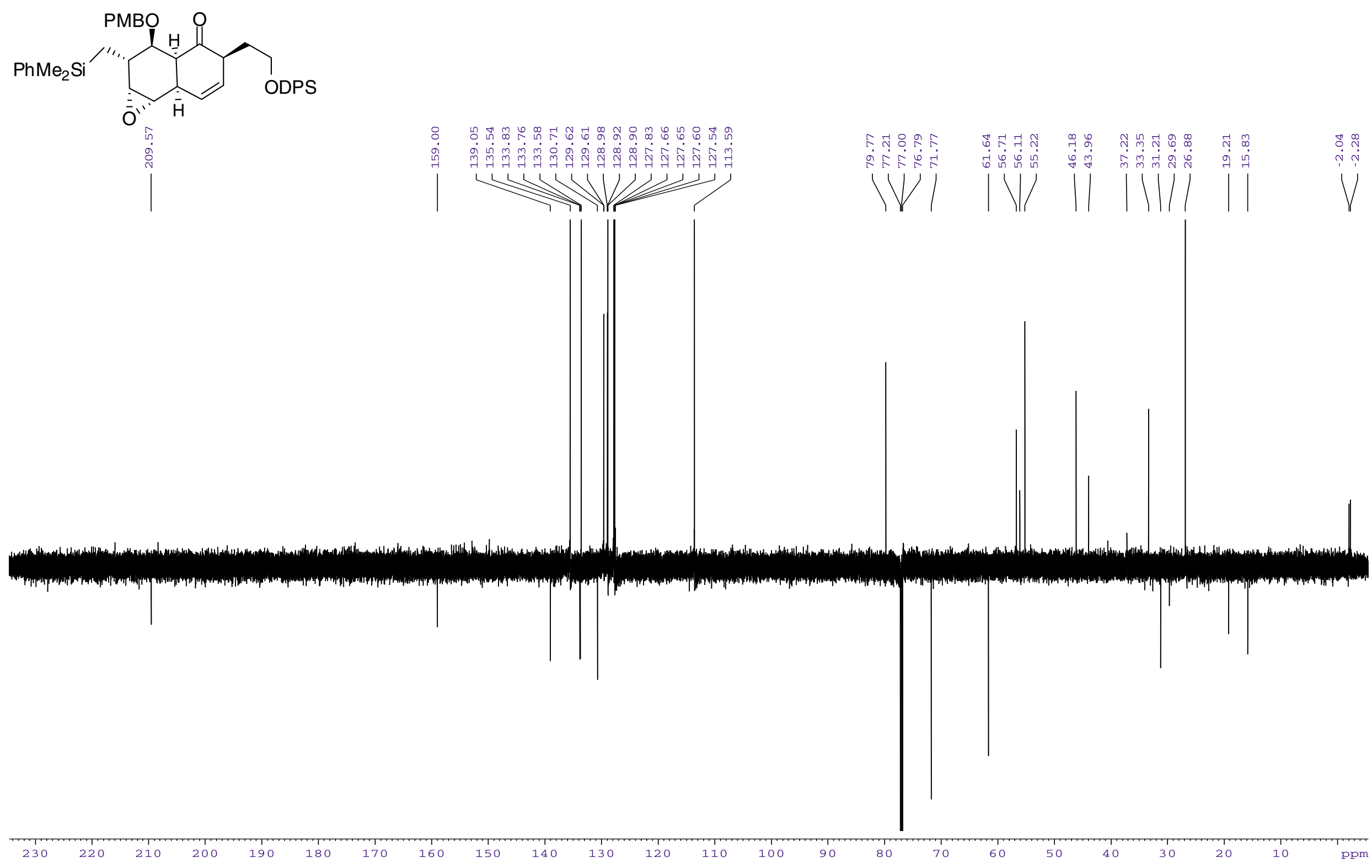



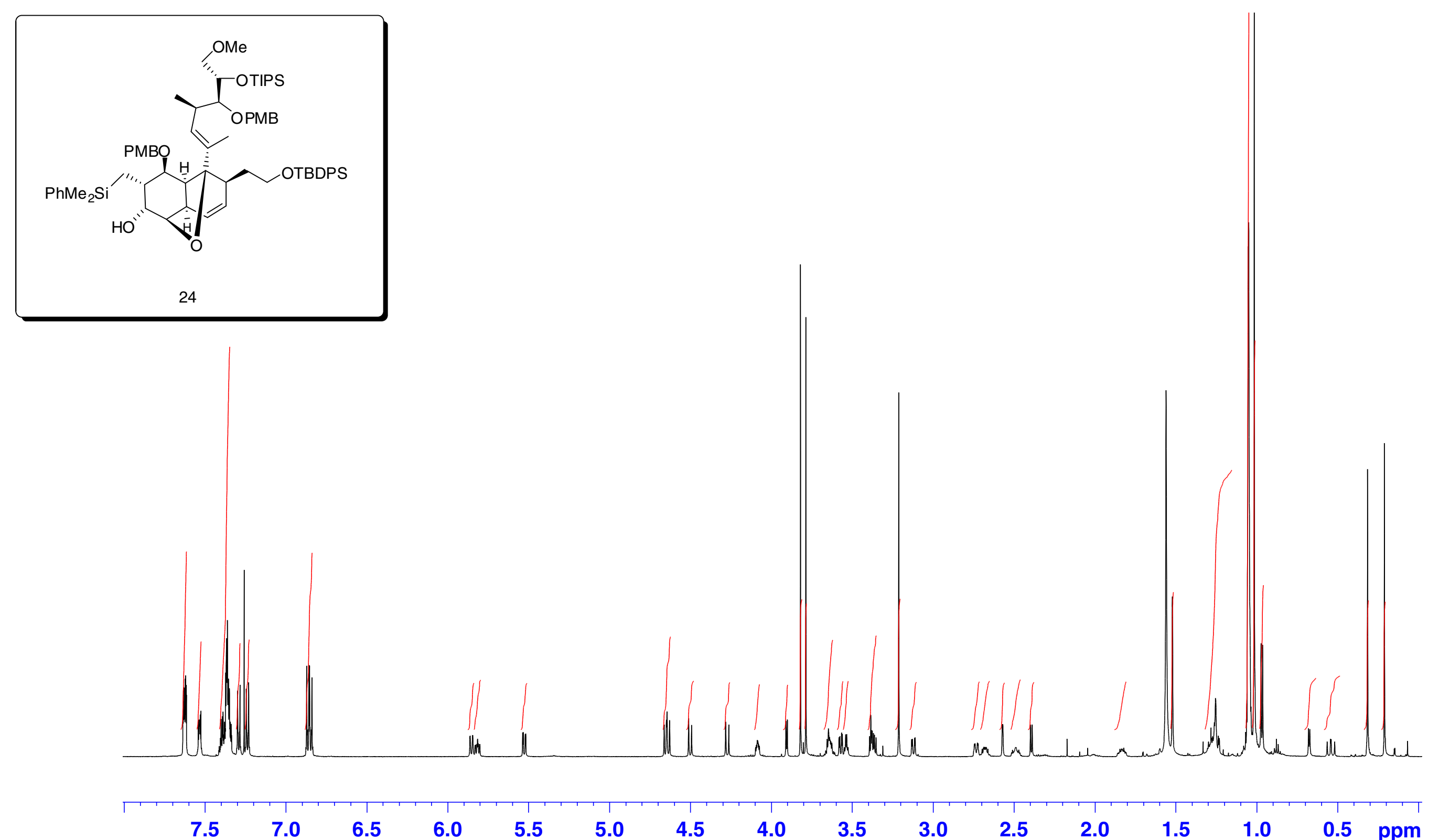

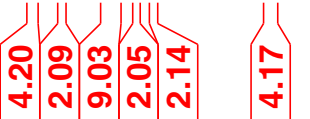
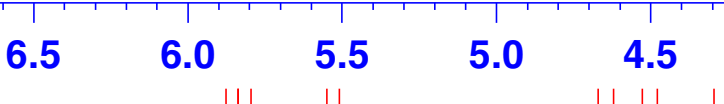

4.0

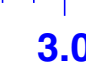

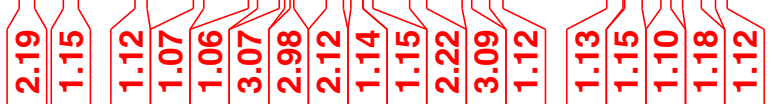

2.0

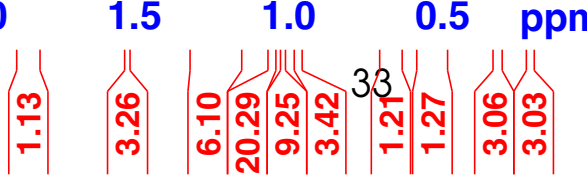




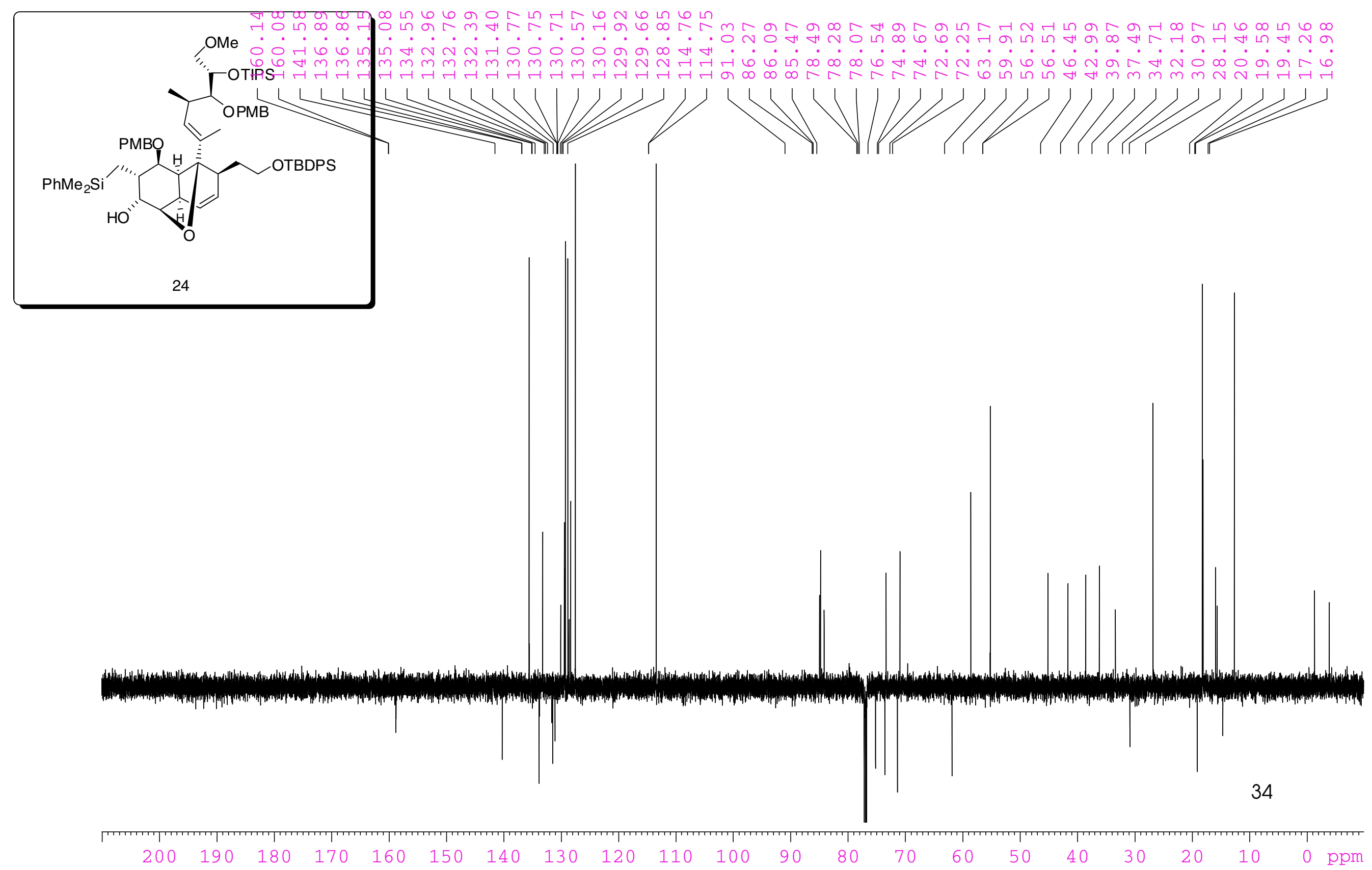


2D COSY of 24. 


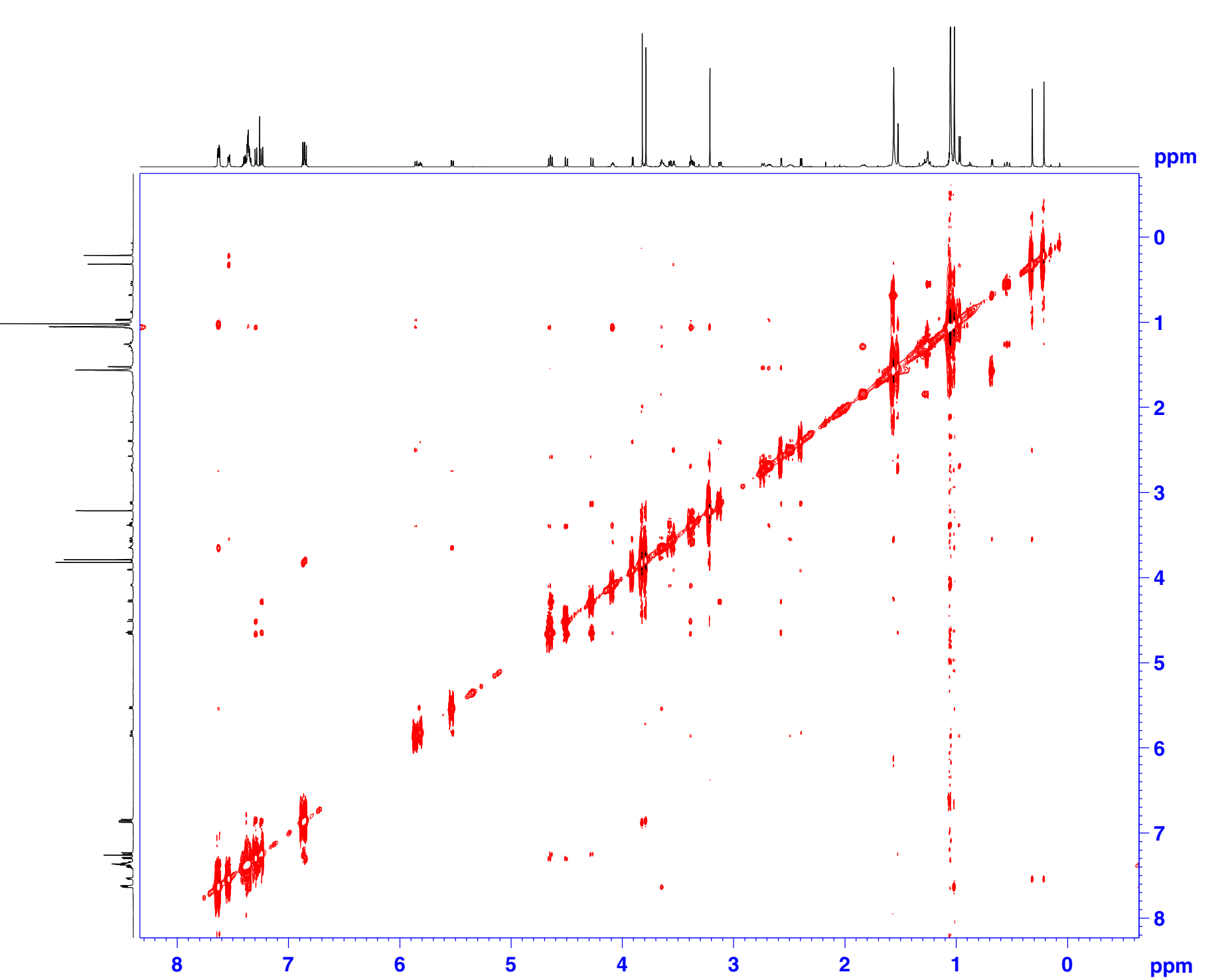


2D NOESY of 24

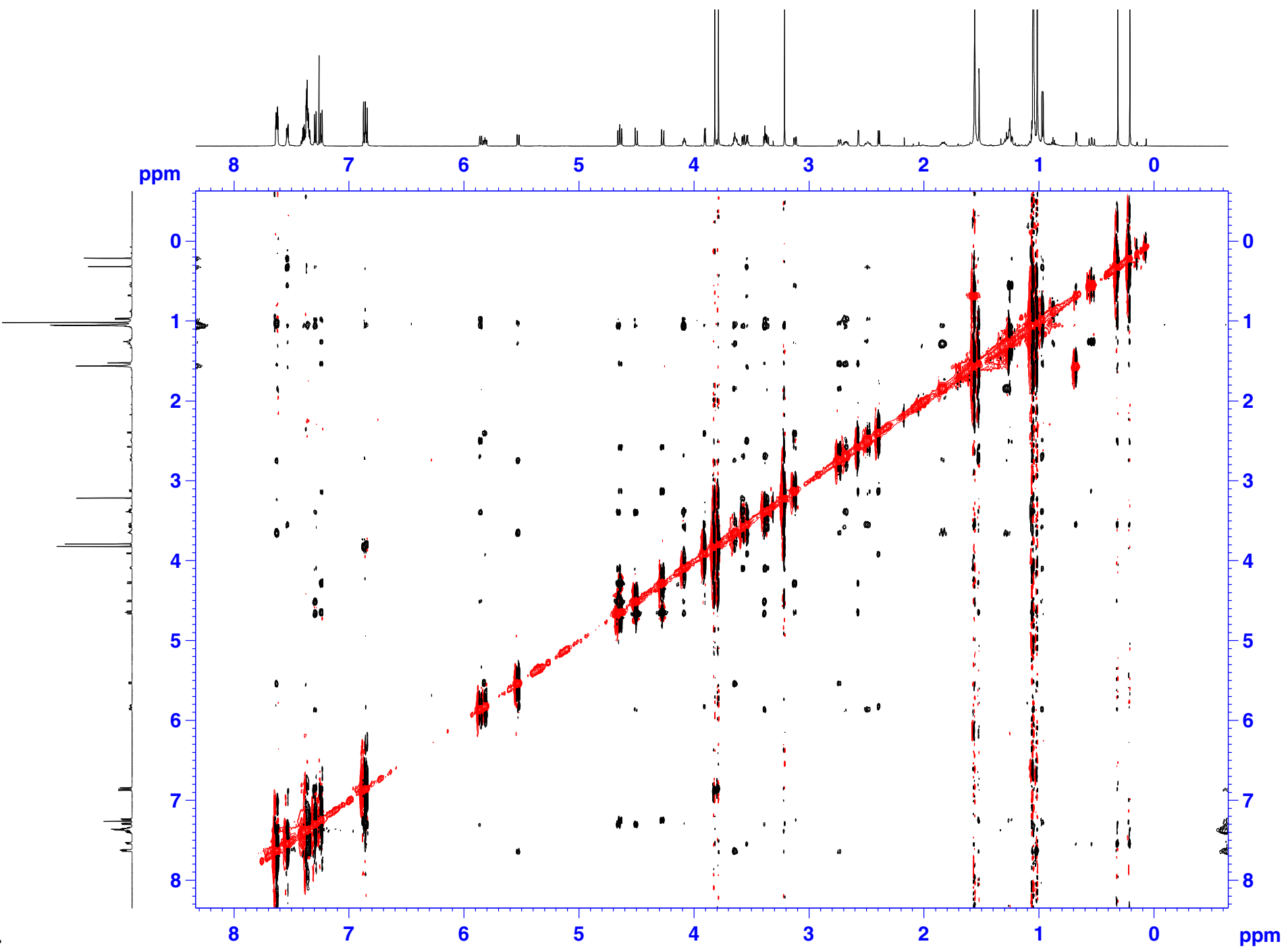

37 